\title{
Thermoregulatory Phenotype of the Trpv1 Knockout Mouse: Thermoeffector Dysbalance with Hyperkinesis
}

\author{
Andras Garami, ${ }^{1}$ Eszter Pakai, ${ }^{1}$ Daniela L. Oliveira, ${ }^{1}$ Alexandre A. Steiner, ${ }^{1}$ Samuel P. Wanner,,${ }^{1,2}$ M. Camila Almeida, ${ }^{1}$ \\ Vladimir A. Lesnikov, ${ }^{3}$ Narender R. Gavva, ${ }^{4}$ and Andrej A. Romanovsky ${ }^{1}$ \\ ${ }^{1}$ Systemic Inflammation Laboratory, Trauma Research, St. Joseph's Hospital and Medical Center, Phoenix, Arizona 85013, ${ }^{2}$ Department of Physiology \\ and Biophysics, Federal University of Minas Gerais, Belo Horizonte, Minas Gerais 31270-901, Brazil, ${ }^{3}$ Fred Hutchinson Cancer Research Center, Seattle, \\ Washington 98109, and ${ }^{4}$ Department of Neuroscience, Amgen, Thousand Oaks, California 91320
}

This study aimed at determining the thermoregulatory phenotype of mice lacking transient receptor potential vanilloid-1 (TRPV1) channels. We used Trpv1 knockout (KO) mice and their genetically unaltered littermates to study diurnal variations in deep body temperature $\left(T_{\mathrm{b}}\right)$ and thermoeffector activities under basal conditions, as well as thermoregulatory responses to severe heat and cold. Only subtle alterations were found in the basal $T_{\mathrm{b}}$ of $\operatorname{Trpv} 1 \mathrm{KO}$ mice or in their $T_{\mathrm{b}}$ responses to thermal challenges. The main thermoregulatory abnormality of $\operatorname{Trpv} 1 \mathrm{KO}$ mice was a different pattern of thermoeffectors used to regulate $T_{\mathrm{b}}$. On the autonomic side, $\operatorname{Trpv} 1 \mathrm{KO}$ mice were hypometabolic (had a lower oxygen consumption) and hypervasoconstricted (had a lower tail skin temperature). In agreement with the enhanced skin vasoconstriction, Trpv1 KO mice had a higher thermoneutral zone. On the behavioral side, Trpv1 KO mice preferred a lower ambient temperature and expressed a higher locomotor activity. Experiments with pharmacological TRPV1 agonists (resiniferatoxin and anandamide) and a TRPV1 antagonist (AMG0347) confirmed that TRPV1 channels located outside the brain tonically inhibit locomotor activity. With age (observed for up to 14 months), the body mass of Trpv1 K0 mice exceeded that of controls, sometimes approaching $60 \mathrm{~g}$. In summary, Trpv1 $\mathrm{KO}$ mice possess a distinct thermoregulatory phenotype, which is coupled with a predisposition to age-associated overweight and includes hypometabolism, enhanced skin vasoconstriction, decreased thermopreferendum, and hyperkinesis. The latter may be one of the primary deficiencies in Trpv1 K0 mice. We propose that TRPV1-mediated signals from the periphery tonically suppress the general locomotor activity.

\section{Introduction}

The development of new pharmacological and genetic tools to work with the transient receptor potential vanilloid-1 (TRPV1) channel has caused a surge of studies aimed at identifying the roles of this channel in various functions, including the regulation of body temperature $\left(T_{\mathrm{b}}\right)$. Studies using pharmacological tools have revealed clear and highly reproducible effects on $T_{\mathrm{b}}$ : TRPV1 agonists cause hypothermia, whereas TRPV1 antagonists cause hyperthermia (for reviews, see Gavva, 2008; Romanovsky et al., 2009). In contrast to the unequivocal results obtained with pharmacological tools, studies in genetically modified animals have failed to reveal a clear thermoregulatory phenotype (Szelé-

Received Sept. 6, 2010; revised 0ct. 25, 2010; accepted Nov. 23, 2010.

This research has been supported by Amgen (study agreements with A.A.R.), the National Institutes of Health (Grant R01NS41233 to A.A.R.), and the National Council for Scientific and Technological Development, Brazil (Visiting Ph.D. Student Fellowship to S.P.W.). We thank Tatiane N. Cooper and Dr. Yury P. Shimansky for the help with the densitometry analysis of thermograms and with statistical analyses, respectively.

N.R.G. is employed by Amgen, Inc. A.A.R. has consulted for Amgen, Inc., and TRP programs at several pharmaceutical companies, and his research has been supported by Amgen, Inc.

Correspondence should be addressed to Andrej A. Romanovsky, Systemic Inflammation Laboratory, Trauma Research, St. Joseph's Hospital and Medical Center, 350 West Thomas Road, Phoenix, AZ 85013. E-mail: aromano@chw.edu.

A. A. Steiner's present address: Department of Pharmaceutical Sciences, Albany College of Pharmacy and Health Sciences, Albany, NY 12208.

M. C. Almeida's present address: Federal University of ABC, Santo Andre, Sao Paulo 09210-170, Brazil.

D0I:10.1523/JNEUROSCI.4671-10.2011

Copyright $\odot 2011$ the authors $\quad 0270-6474 / 11 / 311721-13 \$ 15.00 / 0$ nyi et al., 2004; Iida et al., 2005; Christoph et al., 2008; Motter and Ahern, 2008). Szelényi et al. (2004) have reported that Trpv1 knockout (KO) mice have an exaggerated magnitude of daynight fluctuations in $T_{\mathrm{b}}$, whereas Iida et al. (2005) have not seen such an exaggeration. Motter and Ahern (2008) have found that Trpv1 KO mice have an enhanced capacity for cold-induced thermogenesis, whereas Iida et al. (2005) have not seen such an enhancement. Knowing that thermoregulatory responses in mice are notoriously difficult to study (Rudaya et al., 2005), we reexamined the ability of Trpv1 KO mice to regulate $T_{\mathrm{b}}$. Because thermoeffectors are regulated independently (Romanovsky, 2007; Morrison et al., 2008; McAllen et al., 2010), we studied several autonomic and behavioral effector mechanisms. Because ambient temperature $\left(T_{\mathrm{a}}\right)$ affects many thermoregulatory responses and often determines the pattern of effectors used to regulate deep $T_{\mathrm{b}}$ (Romanovsky et al., 2002), the present study was conducted under tightly controlled thermal conditions. Furthermore, it was verified in each experimental setup used whether the thermal conditions were neutral [i.e., within the thermoneutral zone (TNZ)], subneutral, or supraneutral.

Initially, the primary goal of this study was to determine a thermoregulatory phenotype of the Trpv1 KO mouse. After we found that the absence of the Trpv1 gene was accompanied by an increased locomotor activity, which is considered to be a thermoregulatory effector in small rodents (Mount and Willmott, 1967; Brown et al., 1991; Weinert and Waterhouse, 1998), we focused 
the second part of the study on this novel finding. In pharmacological experiments, we used TRPV1 agonists and a TRPV1 antagonist to investigate the potential involvement of TRPV1 channels in the regulation of locomotor activity. Based on experiments with Trpv1 KO mice and with pharmacological tools, we propose that tonic activation of peripheral TRPV1 channels suppresses the general locomotor activity. Even though TRPV1 channels are unlikely to be those long-sought thermosensors that respond to skin temperature $\left(T_{\mathrm{sk}}\right)$ or deep $T_{\mathrm{b}}$ signals to regulate thermoeffector activity (Romanovsky et al., 2009), the tonic, nonthermal activation of TRPV1 channels does modulate several effector responses (Steiner et al., 2007), perhaps in a state-specific manner (Kanizsai et al., 2009). It is likely, therefore, that new mechanisms relevant to the TRPV1-dependent modulation of $T_{\mathrm{b}}$ remain to be discovered.

\section{Materials and Methods}

\section{Animals}

Physiological experiments were conducted in 293 adult mice of both sexes. Of these, 269 C57BL/6x129 mice were obtained from the Amgen colony at Charles River Laboratories. These mice had the Trpv1 gene either present $\left(\operatorname{Trp} v 1^{+/+}\right)$or missing $\left(\operatorname{Trp} v 1^{-/-}\right)$due to a targeted null mutation (Caterina et al., 2000). They were produced by breeding $\operatorname{Trpv1} 1^{+/-}$males and females and genotyping their offspring; the breeding and genotyping were performed by Charles River Laboratories at their facilities. Twenty-four additional $\operatorname{Tr} p v 1^{+/+}$mice of a different genotype, C57BL/6, were purchased from Charles River Laboratories. Except for the body mass comparison study, where the mice were observed for an extended period of time (from the age of 4 weeks to the age of 56 weeks), all experiments were performed in male mice with body mass of $\sim 30 \mathrm{~g}$ (age of $\sim 17$ weeks). The mice were housed in standard "shoebox" cages kept in a Maxi-Miser ventilated rack (Thoren Caging Systems) at a $T_{\mathrm{a}}$ of $27^{\circ} \mathrm{C}$. The room was on a $12 \mathrm{~h} \mathrm{light/dark} \mathrm{cycle} \mathrm{(lights} \mathrm{on} \mathrm{at} \mathrm{6:00} \mathrm{A.M.).}$ Tap water and standard (5.0\% fat) rodent chow (Laboratory rodent diet 5001; Labdiet) were available ad libitum. The body mass of mice was measured regularly with a portable digital scale (model VI-200; Acculab). At the end of the study, we confirmed the absence or presence of functional TRPV1 channels in the $\mathrm{KO}$ and control mice, respectively. For this, $24 \operatorname{Trpv1}^{-/-}$and $24 \operatorname{Trpv1}^{+/+} \mathrm{C} 57 \mathrm{BL} / 6 \times 129$ mice were randomly selected from the study population, food deprived for $36 \mathrm{~h}$, and then exposed to an excessive amount of habanero chili (Capsicum chinense). Habanero is one of the hottest chili peppers with a reported pungency of 100,000-300,000 Scoville units (Berkley and Jacobson, 1992). For a 20 min period, eating events were counted by an observer blind to the mice's genotype. Trpv1 KO mice eagerly consumed the peppers, whereas the controls did not $(p<0.0001)$ (Fig. 1).

For all experiments, the mice were extensively handled ( 8 daily sessions, $5 \mathrm{~min}$ each) and then habituated to experimental setups as follows. A mouse designated for an experiment in the telemetry, thermocouple, or respirometry setup (see below, Experimental setups), was adapted to staying in either a Plexiglas enclosure or a wire-mesh confiner ( 8 training sessions, $1-4 \mathrm{~h}$ each $)$. The enclosure, which had a square $(15 \times 15 \mathrm{~cm})$ base and 25-cm-high walls, did not limit the animal's movement; it was used for experiments in the telemetry setup. The cylindrical confiner (length, $10 \mathrm{~cm}$; diameter, $3 \mathrm{~cm}$ ) prevented the animal from turning around but allowed for some back-and-forth movements; it was used in the thermocouple and respirometry setups. A mouse designated for an experiment in the thermogradient setup was adapted to staying in the channels of the thermogradient apparatus ( 7 sessions, 3-24 h each). During long training sessions $(>12 \mathrm{~h})$ the animal had unlimited access to food and water. All protocols were approved by the St. Joseph's Hospital and Medical Center Animal Care and Use Committee.

\section{Surgical preparations}

Anesthesia and perioperative care. Surgeries were performed under ketamine-xylazine-acepromazine (81.7, 9.3 , and $1.2 \mathrm{mg} / \mathrm{kg}$, i.p.) anesthesia and antibiotic protection (enrofloxacin, $1.1 \mathrm{mg} / \mathrm{kg}$, s.c.). During surgery, a mouse was heated with a Deltaphase isothermal pad (Braintree

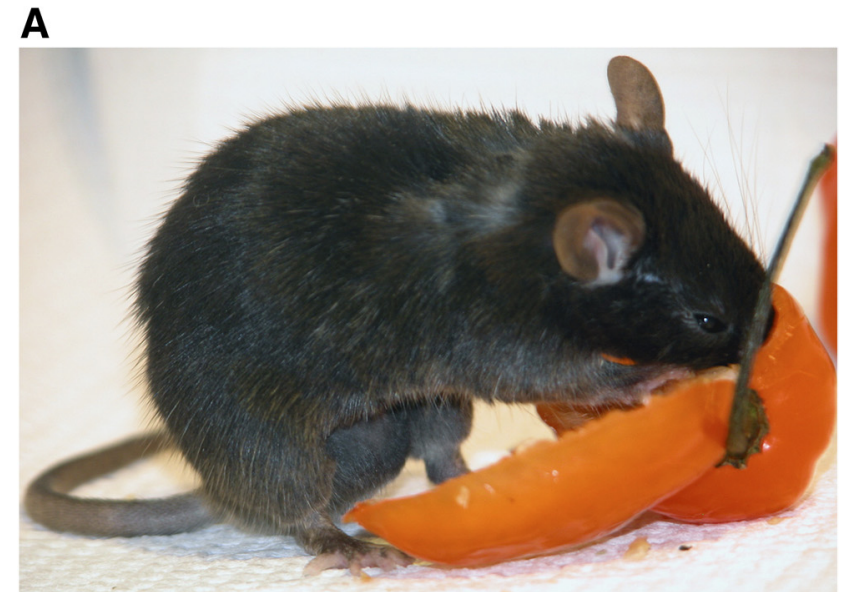

B

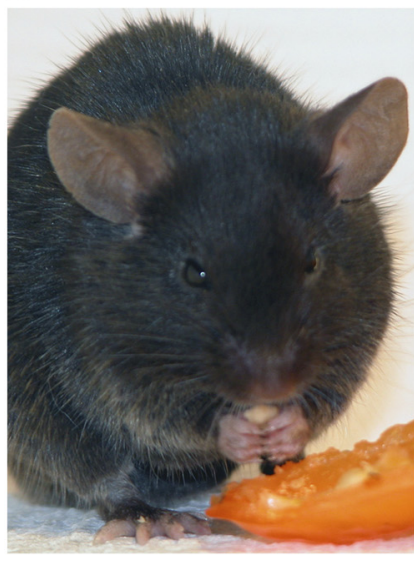

C

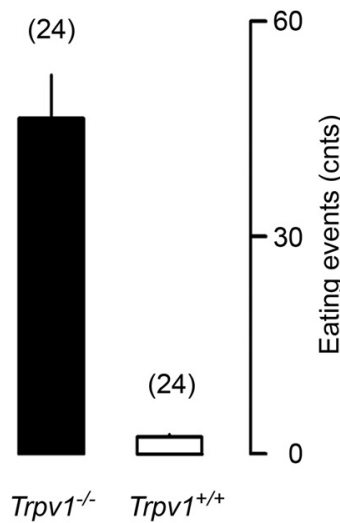

Figure 1. Behavioral verification of TRPV1 deficiency in Trpv1 K0 mice. Trpv1 K0 mice are insensitive to capsaicin and, when food deprived, eagerly consume habanero chili $(\boldsymbol{A})$, including the hottest parts, such as the septa and seeds $(\boldsymbol{B})$. The mean number of pepper-eating events in $\operatorname{Trpv} 1^{-1-}$ versus $\operatorname{Trpv} 1^{+/+}$mice over a 20 min period is also shown (C). Here and in Figures 2, 3 , and $5-10$, numbers in parentheses are the numbers of animals in the corresponding groups.

Scientific) and periodically (every $5 \mathrm{~min}$ ) ventilated with oxygen through a custom-made mask. The isothermal pad was placed either under a surgery board (Plas-Labs) or on the base of a stereotaxic apparatus. For immediate postoperative recovery, the mouse was placed in a climatic chamber set to a $T_{\mathrm{a}}$ of $31.0^{\circ} \mathrm{C}$. Experiments were performed $5-7 \mathrm{~d}$ after surgery.

Implantation of temperature-measuring devices. If the mouse was designated for an experiment in the telemetry setup, it was implanted with a miniature telemetry transmitter (G2 E-Mitter series; Mini Mitter) to record abdominal temperature $\left(T_{\mathrm{ab}}\right.$, a measure of deep $\left.T_{\mathrm{b}}\right)$ and gross locomotor activity. If the mouse was designated for an experiment in the thermogradient setup, it was implanted with a miniature temperature datalogger (Subcue Dataloggers) to record and store $T_{\mathrm{ab}}$ data. Either device was inserted into the peritoneal cavity via midline laparotomy and fixed to the lateral abdominal wall (right side) with a suture. The surgical wound was sutured in layers.

Intraperitoneal catheterization. For the intraperitoneal administration of drugs, a silicone catheter filled with pyrogen-free saline was inserted into the peritoneal cavity through the same opening in the abdominal wall that was used to insert a temperature-measuring device, and the internal end of the catheter was attached with a suture to the lateral abdominal wall on the left side. The free end of the catheter was knotted, tunneled under the skin to the nape, and exteriorized. The catheter was flushed with saline on the day after surgery and every other day thereafter.

Intracerebroventricular cannulation. For the intracerebroventricular drug administration, a 22 ga steel guide cannula (Plastics One) was im- 
Table 1. Experimental setups

\begin{tabular}{|c|c|c|c|}
\hline \multirow[b]{2}{*}{ Setup } & \multicolumn{2}{|c|}{ Measures of deep body temperature $\left(T_{\mathrm{b}}\right)$ and thermoeffector activities studied } & \multirow[b]{2}{*}{ Neutral ambient temperature $\left(T_{\mathrm{a}},{ }^{\circ} \mathrm{C}\right)^{a}$} \\
\hline & $T_{\mathrm{b}}$ & Thermoeffector activities & \\
\hline Telemetry & Abdominal $\left(T_{\mathrm{ab}}\right)$ & $\begin{array}{l}\text { Gross locomotor activity (measured as frequency of probe movement) } \\
\text { Tail skin vasomotion (measured as tail skin temperature, } I_{\text {sk' }} \text {, by thermocouple thermometry }\end{array}$ & 31.0 \\
\hline Thermocouple & Colonic $\left(T_{c}\right)$ & or as radiant $T_{\mathrm{sk}}$ by infrared thermography) & $32.0^{b}$ \\
\hline Respirometry & $T_{\mathrm{c}}$ & Thermogenesis (measured as rate of oxygen consumption, $V_{0_{2}}$ ), tail skin vasomotion $\left(T_{\mathrm{sk}}\right)$ & $33.0^{c}$ \\
\hline Thermogradient & $T_{\mathrm{ab}}$ & Selection of preferred $T_{\mathrm{a}}$, locomotor activity (measured as velocity of longitudinal locomotion) & $27.0^{d}$ \\
\hline
\end{tabular}

${ }^{a}$ For each setup, the table lists one $T_{\mathrm{a}}$ that has been shown to be within the TNZ for Trpv $1^{+/+} \mathrm{CB} 57 \mathrm{BL} / 6$ mice in that setup. ${ }^{b}$ For the lower and upper limits of the TNZ for Trpv $1^{-/-}$and $\operatorname{Trpv} 1^{+/+} \mathrm{CB} 57 \mathrm{BL} / 6 \mathrm{x} 129$ mice in the thermocouple

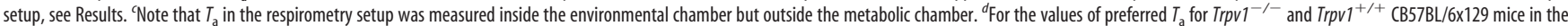
thermogradient setup, see Results.

planted into the right lateral brain ventricle using the stereotaxic atlas by Lesnikov and Tsvetkova (1985) and their original stereotaxic apparatus. The head of a mouse was fixed in the stereotaxic apparatus; the scalp was incised over the sagittal suture; the periosteum was excised; the bone surface was cleaned; and three supporting microscrews were driven into the skull. The position of the head of the mouse was then adjusted so that bregma was located $0.5 \mathrm{~mm}$ higher than lambda, and a hole was drilled $0.5 \mathrm{~mm}$ posterior to bregma and $1.0 \mathrm{~mm}$ right of the sagittal suture. The guide cannula with a 28 ga dummy injector inside was inserted into the lateral ventricle by lowering the tip of the injector (which protruded the cannula by $1.0 \mathrm{~mm}$ ) $3.0 \mathrm{~mm}$ below the skull surface. The cannula was affixed to the supporting microscrews with acrylic cement. At the end of the experiments, a correct placement of each cannula was confirmed by anesthetizing the animal, infusing $3 \mu \mathrm{l}$ of an aqueous solution of methylene blue $(6 \mathrm{mg} / \mathrm{ml})$ through the cannula, removing the brain, and examining coronal sections macroscopically for the presence of the dye in the ventricular system.

\section{Experimental setups}

Experiments were conducted in one of the following setups: the telemetric thermometry ("telemetry") setup, the thermocouple thermometry ("thermocouple") setup, the thermocouple thermometry with respirometry ("respirometry") setup, and the thermogradient setup (Table 1). All experiments, unless specified otherwise, were conducted under thermoneutral conditions. Because the same animal has a different TNZ in each setup (Romanovsky et al., 2002), the setups were used at different $T_{\mathrm{a}} \mathrm{s}$ (Table 1). In these setups, we measured deep $T_{\mathrm{b}}$ [as either $T_{\mathrm{ab}}$ or colonic temperature $\left.\left(T_{c}\right)\right]$ and four thermoeffector activities, two autonomic and two behavioral (Table 1). On the autonomic side, we measured tail skin vasomotion (assessed by tail skin temperature, $T_{\mathrm{sk}}$ ) and the rate of oxygen consumption $\left(V_{\mathrm{O}_{2}}\right)$. On the behavioral side, we measured the preferred $T_{\mathrm{a}}$ and general locomotor activity. The latter has been shown repeatedly to play an important thermoregulatory role in small rodents such as rats and mice (Mount and Willmott, 1967; Brown et al., 1991; Weinert and Waterhouse, 1998) and is now widely viewed as a thermoregulatory effector in these species (Kanizsai et al., 2009; Hunt et al., 2010; Szentirmai et al., 2010). The locomotor activity was measured in this study either as the velocity of longitudinal movement in the thermogradient apparatus or as the frequency of changes of the position or orientation of the implanted telemetry probe in the telemetry setup.

Telemetry setup. Telemetry receivers (model ER-4000; Mini Mitter) were positioned inside a climatic chamber (model 3940; Forma Scientific). The home cage of each mouse was placed on top of a receiver; a Plexiglas enclosure was placed inside the cage; and the mouse was left in the enclosure. The mouse was preimplanted with a telemetry transmitter (to measure $T_{\mathrm{ab}}$ and locomotor activity). In a subset of mice, the transmitter was implanted in combination with either an intraperitoneal catheter or an intracerebroventricular cannula for drug administration. If the mouse had an intraperitoneal catheter, the catheter was extended with a length of polyethylene-50 tubing filled with a drug of interest. This extension was passed through a wall port of the climatic chamber and connected to a syringe placed in an infusion pump (model KDS 220; KD Scientific). Whereas most experiments in this setup were conducted at a neutral $T_{\mathrm{a}}$ of $31.0^{\circ} \mathrm{C}$ (Table 1 ), a subneutral $T_{\mathrm{a}}$ of $26.0^{\circ} \mathrm{C}$ was used when the expected experimental outcome was a decrease in $T_{\mathrm{b}}$, e.g., in experiments with administration of TRPV1 agonists (Hori, 1984; Romanovsky et al., 2009).
We had a concern that measuring locomotor activity with G2 telemetry probes might overestimate any meaningful locomotion, because this method picks up changes not only in the position of the probe relative to the receiver, but also in the probe orientation. Hence, there was a possibility that breathing movements, intestinal peristalsis, yawning, coughing, shivering, and similar activities may contaminate the results or even mask any changes in true whole-body locomotion. To address this concern, we conducted a separate series of experiments. We mounted a motion sensor (Infrared Cage Top Motion Sensor; Mini Mitter), which works with Mini Mitter hardware and software, on each Plexiglas enclosure and simultaneously recorded locomotor activity with the implanted G2 probes and with the external motion sensors. The external sensorbased method is completely insensitive to any probe movement inside the peritoneal cavity, and requires a true body movement to register an activity event. Two groups of Trpv1 $1^{+/+}$C57BL/6x129 and two groups of $\operatorname{Trpv1} 1^{+/+} \mathrm{C} 57 \mathrm{BL} / 6$ mice were injected intraperitoneally with either resiniferatoxin (RTX) or anandamide (AEA), or with their vehicle, as described below. In all four groups, the activity curves obtained by the two methods looked nearly identical (see Notes). When the obtained activity curves were analyzed by two-way ANOVA (following a linear unit transformation), no significant differences were found in any group. These experiments confirm that the telemetric activity measure is a reliable indicator of locomotor activity.

Thermocouple setup. A mouse equipped with copper-constantan thermocouples (Omega Engineering) to measure $T_{\mathrm{c}}$ and $T_{\mathrm{sk}}$ was placed in a confiner. The colonic thermocouple was inserted $2 \mathrm{~cm}$ beyond the anal sphincter and fixed to the base of the tail with a loop of adhesive tape. The skin thermocouple was positioned on the lateral surface of the tail (at the boundary of the proximal and middle thirds) and insulated from the environment with tape. The thermocouples were plugged into a data logger (Cole-Parmer). The confiner with the mouse inside was transferred to a climatic chamber. Whereas most experiments in this setup were conducted at a neutral $T_{\mathrm{a}}$ of $32.0^{\circ} \mathrm{C}$ (Table 1 ), this setup was also used for heat-exposure experiments, in which $T_{\mathrm{a}}$ was raised from 31.0 to $39.0^{\circ} \mathrm{C}$ over $\sim 30 \mathrm{~min}$ and then maintained at $39.0^{\circ} \mathrm{C}$.

In a separate series of experiments, thermocouples were not used, and radiant $T_{\mathrm{sk}}$ was monitored by infrared thermography with a ThermoVision A20M camera (FLIR Systems) to assess the vasomotor tone of the tail skin and to determine the TNZ (Romanovsky et al., 2002). The ThermoVision camera was positioned above a group of confined mice inside the climatic chamber set to $T_{\mathrm{a}}$ randomly selected from the following list: $30.0,30.5,31.5,32.0,32.5,33.0,33.5$, or $35.0^{\circ} \mathrm{C}$. The mice were kept at this $T_{\mathrm{a}}$ for $\sim 2 \mathrm{~h}$, and infrared thermograms were taken. Thereafter, $T_{\mathrm{a}}$ was changed in a stepwise fashion to another value from the same list and maintained at this new level for $\sim 2 \mathrm{~h}$. Infrared thermograms of the mice were taken again, and a new $T_{\mathrm{a}}$ was chosen. Usually, three to four temperatures were studied in the same experiment.

Respirometry setup. Each mouse was equipped with thermocouples as for experiments in the thermocouple setup. Then each mouse in its confiner was placed inside a cylindrical Plexiglas chamber (Sable Systems), which was sealed. The Plexiglas chambers with mice inside were kept in a climatic chamber and continuously ventilated. The airflow was maintained at $600 \mathrm{ml} / \mathrm{min}$ with the help of a mass flow controller (Sierra Instruments). The air leaving each chamber was automatically sampled, dried, and passed through an oxygen analyzer (Sable Systems). The rate 
of $V_{\mathrm{O}_{2}}$ was calculated by comparing the oxygen fraction in the air exiting the chamber occupied by a mouse to the oxygen fraction in the air exiting an empty chamber (see below, Data processing and analysis). Whereas most experiments in this setup were conducted at a neutral $T_{\mathrm{a}}$ of $33.0^{\circ} \mathrm{C}$ (Table 1 ), this setup was also used for exposing mice to cold. Cooling was performed by decreasing $T_{\mathrm{a}}$ in the climatic chamber from $33.0^{\circ} \mathrm{C}$ to $5.0^{\circ} \mathrm{C}$ over $150 \mathrm{~min}$.

Thermogradient setup. The thermogradient apparatus used has been described in detail previously (Almeida et al., 2006). The apparatus consisted of six 200-cm-long aluminum channels. Each channel had a second (inner) stainless-steel grid floor and an acrylic double-wall lid at the top. At each end, all channels shared a common aluminum wall, which separated the channels from a large tank. The tank at the "warm" end of the channels was filled with water warmed with two electric heating units (PolyScience) to maintain $T_{\mathrm{a}}$ inside the channels at this end at $30.0^{\circ} \mathrm{C}$. The tank at the "cold" end was constantly perfused with $10 \%$ ethylene glycol by an external-circulation cooling/heating pump (PolyScience) to maintain $T_{\mathrm{a}}$ inside the channels at this end at $20.0^{\circ} \mathrm{C}$. In this setting, all channels had a common, nearly linear longitudinal $T_{\mathrm{a}}$ gradient of $0.05^{\circ} \mathrm{C} /$ $\mathrm{cm}$. The position of a mouse in a channel of the thermogradient apparatus was monitored with 56 evenly spaced $(3.5 \mathrm{~cm})$ infrared emitterreceiver pairs, which formed transversal infrared beams. This system also allowed us to directly measure the longitudinal locomotor activity. By knowing how the position of an animal changed in time (as the animal crossed the beams), we knew the velocity of the longitudinal movement (distance traveled divided by time).

\section{Drugs and drug administration}

RTX, a highly potent TRPV1 agonist, was purchased from SigmaAldrich. An ethanolic stock solution of RTX $(200 \mu \mathrm{g} / \mathrm{ml})$ was prepared, aliquoted, and stored at $-80^{\circ} \mathrm{C}$. On the day of the experiment, the stock was diluted with ethanol and saline to achieve a final concentration of RTX of 6,60 , or $150 \mathrm{ng} / \mathrm{ml}$ and a final concentration of ethanol of $10 \%$. For the intraperitoneal administration, this working solution (or the vehicle) was injected acutely, as a bolus ( $3.3 \mathrm{ml} / \mathrm{kg}$ ), using a 26 ga needle. For the intracerebroventricular administration, the same working solution of RTX (or the vehicle) was infused ( $1.5 \mu \mathrm{l} / \mathrm{min}$ ) over a $2 \mathrm{~min}$ period. At these infusion volumes and rates, even much higher concentrations of ethanol (50\%) do not cause behavioral responses or changes in $T_{\mathrm{b}}$ (Steiner et al., 2007). For the infusion, the dummy injector (mandrin) was removed from the preimplanted guide cannula and replaced with a 28 ga injector needle (Plastics One) connected to a $25 \mu$ l Hamilton syringe by a polyethylene-50 extension. The injector needle protruded $1.0 \mathrm{~mm}$ beyond the tip of the guide cannula. At the end of the infusion, the injector was held in place for an additional $1 \mathrm{~min}$ and then removed and replaced with the mandrin.

AEA (arachidonoyl $N$-ethanolamide), purchased from Tocris Bioscience, was used in the present study as a TRPV1 agonist (Zygmunt et al., 1999; Smart et al., 2000). An ethanolic solution of AEA ( $5 \mathrm{mg} / \mathrm{ml})$ was stored at $-20^{\circ} \mathrm{C}$. On the day of the experiment, the stock was diluted with ethanol and saline to achieve a final concentration of AEA of $0.5 \mathrm{mg} / \mathrm{ml}$ in $10 \%$ ethanol. This working solution of AEA $(15 \mathrm{mg} / \mathrm{kg})$ or the vehicle ( $10 \%$ ethanol) was injected intraperitoneally as a bolus at a total volume of 30 $\mathrm{ml} / \mathrm{kg}$. Because one of the expected outcomes of experiments with TRPV1 agonists was a decrease in the gross locomotor activity (Crawley et al., 1993; Fride and Mechoulam, 1993; Smith et al., 1994; Di Marzo et al., 2001; Wiley et al., 2006), RTX and AEA (or their vehicles) were administered acutely by briefly restricting the animal, pricking it with a needle, bolus injecting the drug, and then releasing the animal. In this paradigm, the handling and needle pricking associated with drug administration elevate the low, nearzero activity typical for habituated mice during the light (inactive) phase.

AMG0347, a highly potent and selective TRPV1 antagonist (Steiner et al., 2007), was provided by Amgen. Aliquots of an ethanolic solution of AMG0347 $(3.5 \mathrm{mg} / \mathrm{ml})$ were stored at $-80^{\circ} \mathrm{C}$. On the day of the experiment, the stock solution was diluted with ethanol and saline to achieve a final concentration of AMG0347 of $15 \mu \mathrm{g} / \mathrm{ml}$ in 50\% ethanol. AMG0347 $(50 \mu \mathrm{g} / \mathrm{kg})$ or its vehicle was administered intraperitoneally as a bolus $(3.3 \mathrm{ml} / \mathrm{kg})$ via a preimplanted catheter. The expected outcome in experiments with AMG0347 was an increase in the locomotor activity. To avoid stress hyperkinesis in these experiments, we used a nonstressful method of intraperitoneal drug administration via a preimplanted cannula.

\section{Data processing and analysis}

The rate of $V_{\mathrm{O}_{2}}$ was calculated by comparing the oxygen fraction in the air exiting the chamber occupied by a mouse $(F)$ to the oxygen fraction in the air exiting an empty chamber $\left(F_{0}\right)$ :

$$
V_{\mathrm{O}_{2}}=\frac{A\left(F_{0}-F\right)}{M-F_{0} M(1+Q)},
$$

where $A$ was air flow, $Q$ was the respiratory quotient (considered to be 0.71 ), and $M$ was the animal's mass (Steiner et al., 2007).

All data collected as time series were compared across genotypes and time points by two-way ANOVA with a Fisher LSD post hoc test, as appropriate. These included the data on deep $T_{\mathrm{b}}$ (whether $T_{\mathrm{ab}}$ or $T_{\mathrm{c}}$ ), measures of thermoeffector activities (i.e., tail $T_{\mathrm{sk}}, V_{\mathrm{O}_{2}}$, preferred $T_{\mathrm{a}}$, and gross locomotor activity), and body mass. For a statistical analysis of the tail images on the infrared thermograms obtained, the optical density was determined for each image by using the VisionWorks 6.5.2 image acquisition and analysis software (Ultra-Violet Products). The optical density values were also compared by two-way ANOVA across genotypes and $T_{\mathrm{a}}$ s. All data collected as single-point measurements (chili pepper eating events) or presented as a single number (light-phase mean, darkphase mean, and daily mean values of $T_{\mathrm{b}}$ measures and those of effector activity measures) were compared between the genotypes by Student's $t$ test. All analyses were performed using Statistica AXA 8.0 (Statsoft). The data are reported as means \pm SE.

\section{Results}

\section{Phase-specific changes in deep $T_{\mathrm{b}}$ of $\operatorname{Trp} v 1 \mathrm{KO}$ mice}

To identify a thermoregulatory phenotype of the Trpv1 KO mouse, we studied circadian fluctuations in deep $T_{\mathrm{b}}$ and thermoeffector activities of a large number of $\operatorname{Tr} p v 1^{-/-}$and $\operatorname{Tr} p v 1^{+/+}$ mice in three experimental setups: thermogradient (Fig. $2 A$ ), telemetry (Fig. $2 B$ ), and respirometry (Fig. $2 C$ ). In all three setups, the light-phase mean deep $T_{\mathrm{b}}$ of $\operatorname{Trp} v 1 \mathrm{KO}$ mice was slightly (by $0.2-0.7^{\circ} \mathrm{C}$ ) but significantly lower than that of the controls (Fig. $2 A-C)$. A similar difference in $T_{\mathrm{b}}$ between the $\mathrm{KO}$ and control mice was found under basal conditions (before any drug administration) in several other experiments in this study (Table 2). During the dark (active) phase, however, the intergenotype $T_{\mathrm{b}}$ difference was attenuated (respirometry setup) (Fig. 2C) or completely disappeared (telemetry setup) (Fig. $2 B$ ). In the thermogradient setup (Fig. $2 \mathrm{~A}$ ), this difference became reversed, that is, the mean dark-phase $T_{\mathrm{ab}}$ of the $\mathrm{KO}$ mice was $0.5^{\circ} \mathrm{C}$ higher than that of the controls $(p<0.05)$. As the result of such biphasic dynamics, the daily mean $T_{\mathrm{b}}$ of $\operatorname{Tr} p v 1 \mathrm{KO}$ mice was either similar to or slightly lower than that of the controls in all setups (Fig. $2 A-C)$. The magnitude of day-night changes in $T_{\mathrm{b}}$ of the $\operatorname{Tr} p v 1$ $\mathrm{KO}$ mice was increased compared to that of the controls in the thermogradient setup $\left(0.8 \pm 0.2\right.$ vs $\left.0.2 \pm 0.1^{\circ} \mathrm{C} ; p<0.05\right)$ and in the telemetry setup $\left(1.0 \pm 0.1\right.$ vs $\left.0.5 \pm 0.1^{\circ} \mathrm{C} ; p<0.01\right)$. It also had a tendency to be increased in the respirometry setup $(0.5 \pm$ 0.1 vs $\left.0.2 \pm 0.2^{\circ} \mathrm{C} ; p<0.1\right)$. In summary, our results agree with studies by others (Szelényi et al., 2004; Iida et al., 2005) showing that Trpv1 KO mice have only slight alterations in the level at which their deep $T_{\mathrm{b}}$ is regulated throughout the day, as compared to control mice. Furthermore, these alterations are phase specific and, to some extent, depend on the experimental setup.

\section{$\operatorname{Trp} v 1 \mathrm{KO}$ mice exhibit a distinct thermoeffector pattern}

What differed drastically between the two genotypes in our study was not the level of $T_{\mathrm{b}}$, but the pattern of behavioral and autonomic effectors used to regulate $T_{\mathrm{b}}$. We studied two behavioral and two autonomic effectors (Table 1). Behavioral effector activities included the "classic" selection of preferred $T_{\mathrm{a}}$ and the gross locomotor activity (Fig. 3A). The autonomic effector activities 


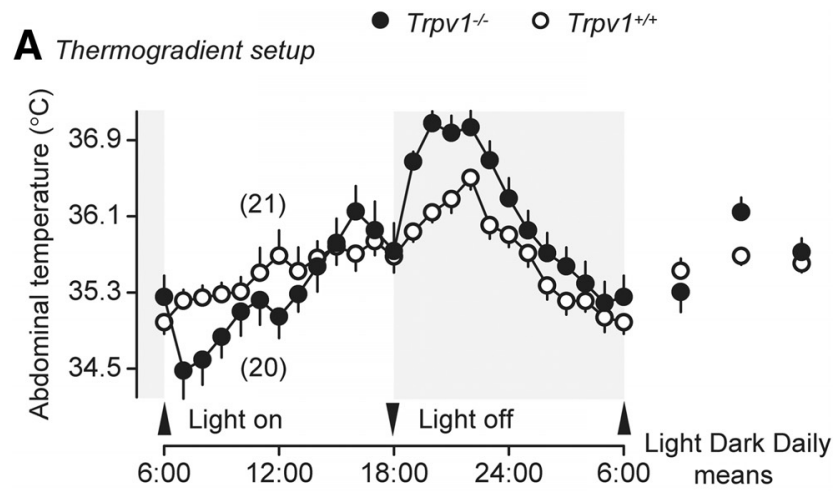

B Telemetry setup

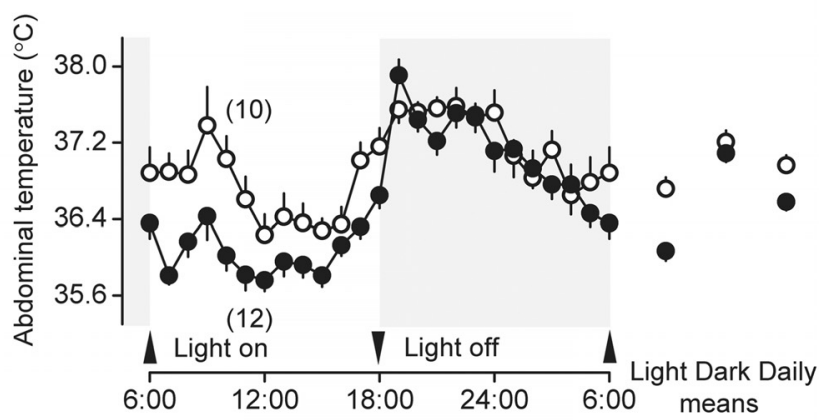

C Respirometry setup

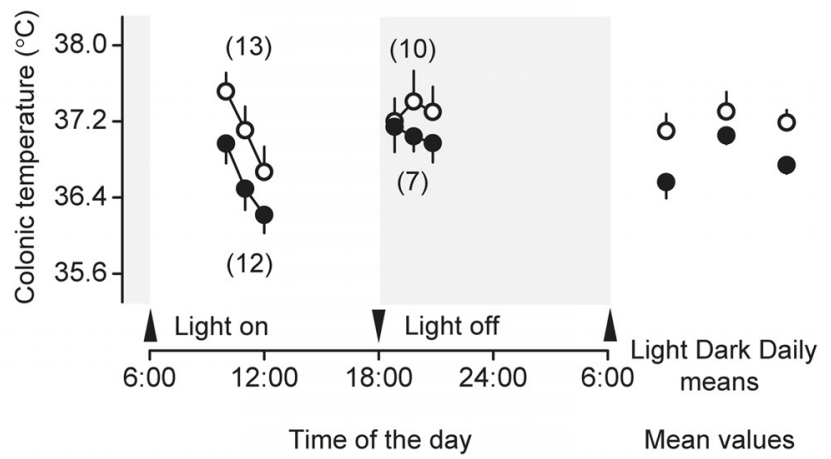

Figure 2. During the inactive (light) phase, $\operatorname{Trpv} 1 \mathrm{~K} 0$ mice have a lower deep $T_{\mathrm{b}}$ than their genetically unaltered counterparts in the thermogradient $(\boldsymbol{A})$, telemetry $(\boldsymbol{B})$, and respirometry $(\boldsymbol{C})$ setups.

Table 2. Basal deep body temperature ( 30 min mean $\pm \mathrm{SE}$ ) of $\operatorname{Trpv} 1^{+/+}$and Trpv1 ${ }^{-/-}$mice in different experimental setups during the light phase

\begin{tabular}{llll}
\hline & \multirow{2}{*}{$\begin{array}{l}\text { Ambient } \\
\text { Experimental setup }\end{array}$} & \multicolumn{2}{l}{ Basal body temperature $\left({ }^{\circ} \mathrm{C}\right), n$} \\
\cline { 3 - 4 } Temperature $\left({ }^{\circ} \mathrm{C}\right)$ & & $\operatorname{Trpv1} 1^{+/+}$ & $\operatorname{Trpv1} 1^{-/-}$ \\
\hline Telemetry & 31.0 & $36.7 \pm 0.1$ & $36.3 \pm 0.1^{a}$ \\
& 28.0 & $n=32$ & $n=35$ \\
& & $36.4 \pm 0.1$ & $36.1 \pm 0.1^{b}$ \\
Thermocouple & 32.0 & $n=14$ & $n=14$ \\
& & $37.1 \pm 0.3$ & $37.3 \pm 0.2$ \\
Respirometry & 33.0 & $n=6$ & $n=6$ \\
& & $36.8 \pm 0.2$ & $36.3 \pm 0.2^{a}$ \\
Thermogradient & $20.0-30.0$ & $n=13$ & $n=12$ \\
& & $35.8 \pm 0.3$ & $35.0 \pm 0.2^{a}$ \\
& & $n=21$ & $n=20$ \\
\hline
\end{tabular}

${ }^{a} p<0.05 ;{ }^{b} p<0.1$.

included thermogenesis (measured as $V_{\mathrm{O}_{2}}$ ) and tail skin vasomotor tone (measured as $T_{\text {sk }}$ ) (Fig. $3 B$ ). All four effector activities were reproducibly altered in the setups studied. On the behavioral side, $\operatorname{Tr} p v 1 \mathrm{KO}$ mice selected a lower $T_{\mathrm{a}}$ than their $\operatorname{Tr} p v 1^{+/+}$
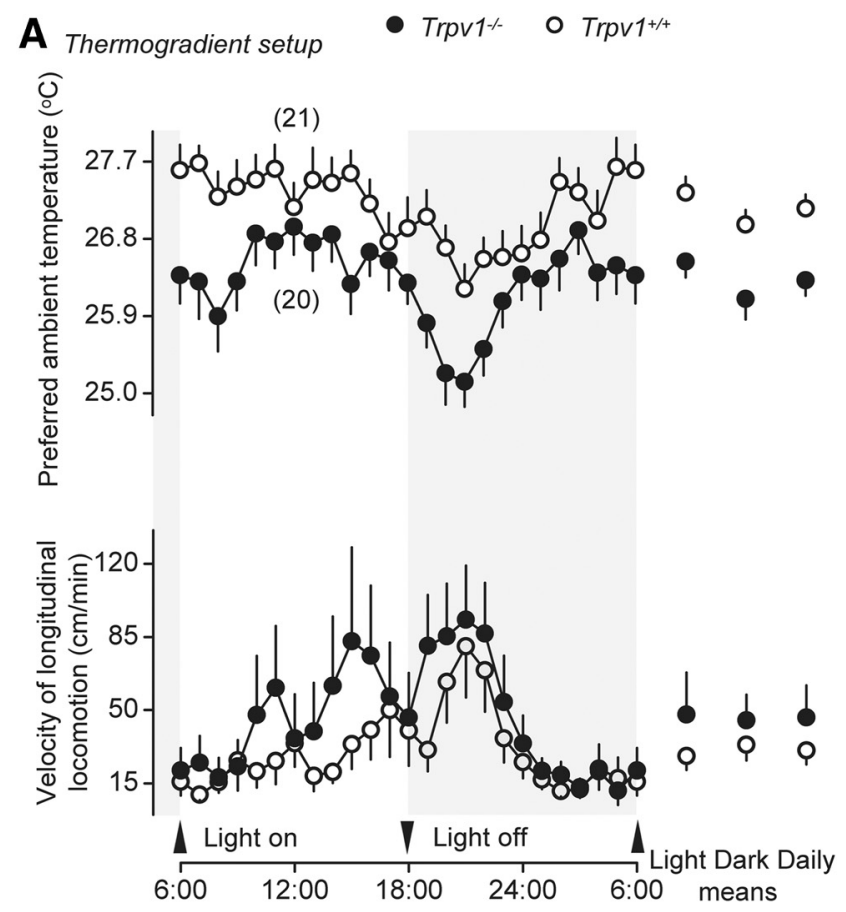

B Respirometry setup

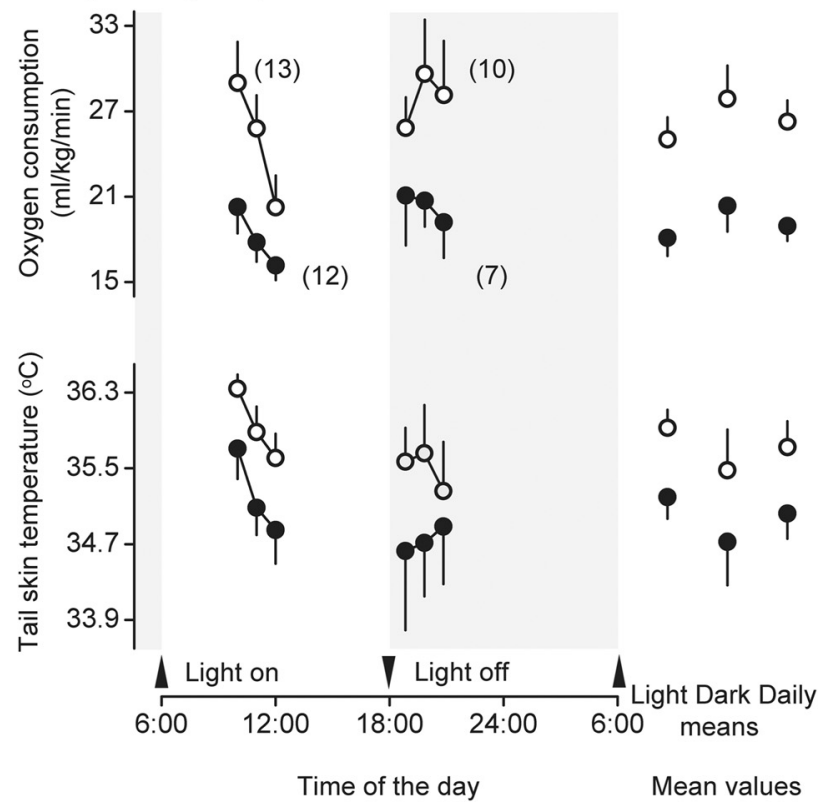

Figure 3. Compared to genetically unaltered controls, $\operatorname{Trpv} 7 \mathrm{~K} 0$ mice regulate $T_{\mathrm{b}}$ by using a different thermoeffector pattern. In the thermogradient setup $(\boldsymbol{A})$, they prefer a lower $T_{\mathrm{a}}$ and are hyperactive. In the respirometry setup $(\boldsymbol{B})$, they are hypometabolic (have a lower $V_{0_{2}}$ ) and vasoconstricted (have a lower tail $T_{\text {sk }}$ ).

counterparts (daily means of $26.3 \pm 0.2$ vs $27.2 \pm 0.2^{\circ} \mathrm{C}$, respectively; $p<0.01$ ), regardless of the phase. Trpv1 KO mice also expressed a higher locomotor activity, especially during the light phase. Although the mean velocities during the light phase, the dark phase, or the entire day did not differ statistically between the genotypes (Student's $t$ test), the $24 \mathrm{~h}$ activity curves were significantly different (ANOVA, $p<0.01$ ). From the biological point of view, the magnitude of the effect was remarkable: at one time point during the inactive phase (3:00 P.M.), Trpv1 KO mice were moving in the thermogradient with an average linear veloc- 
ity of $85 \mathrm{~cm} / \mathrm{min}(>1.2 \mathrm{~km} / \mathrm{d})$, which was $\sim 3$ times higher than the average speed of wild-type mice at the same time of day. Furthermore, it was higher than the locomotion speed of wildtype mice at any time, including the peak of their activity at night. When we measured autonomic thermoeffector activity in the respirometry setup, we found that $\operatorname{Trp} v 1 \mathrm{KO}$ mice maintained a lower metabolic rate and exhibited a more pronounced cutaneous vasoconstriction than the controls, regardless of the phase. The means for $V_{\mathrm{O}_{2}}$ and $T_{\mathrm{sk}}$ for the $\mathrm{KO}$ versus control mice were $18.9 \pm 1.0$ versus $26.3 \pm 1.3 \mathrm{ml} / \mathrm{kg} / \mathrm{min}(p<0.0001)$ and $35.0 \pm$ 0.2 versus $35.7 \pm 0.2^{\circ} \mathrm{C}(p<0.05)$, respectively. The difference in $V_{\mathrm{O}_{2}}$ recorded was not contaminated by the tendency of the two genotypes to have different levels of locomotor activity, as these experiments were performed in restrained animals. In summary, under basal conditions, Trp $1 \mathrm{KO}$ mice have a thermoregulatory phenotype that reveals itself in a distinct thermoeffector pattern. These mice are prone to select a cooler environment; they are also hyperactive, hypometabolic, and vasoconstricted.

\section{Trpv1 KO mice have a higher TNZ}

The TNZ can be defined as a $T_{\mathrm{a}}$ range in which regulation of deep $T_{\mathrm{b}}$ is achieved primarily by changing the vasomotor tone in specialized heat-exchange organs, such as the mouse or rat tail (Romanovsky et al., 2002). Below the TNZ, rodent tails exhibit continuous skin vasoconstriction. Above the TNZ, they show continuous skin vasodilation. Within the TNZ, the tone of tail skin vasculature changes between moderate constriction and moderate dilation and exhibits a high intrasubject and intersubject variation (Romanovsky et al., 2002; Rudaya et al., 2005; Almeida et al., 2006). The fact that Trpv1 KO mice exhibited stronger tail skin vasoconstriction at $T_{\mathrm{a}}$ of $33.0^{\circ} \mathrm{C}$ in the respirometry setup (Fig. 3B), warranted further investigation. Hence, we assessed the TNZ of Trpv1 $1^{-/-}$and Trpv1 ${ }^{+/+}$C57BL/6x129 mice in the thermocouple setup by measuring radiant tail $T_{\mathrm{sk}}$ by infrared thermography. At a high $T_{\mathrm{a}}$ of $35.0^{\circ} \mathrm{C}$ (Fig. $4 A$ ), the tails of all mice studied were strongly and uniformly vasodilated. Under these conditions, $T_{\text {sk }}$ was approaching deep $T_{\mathrm{b}}$ and was substantially higher than $T_{\mathrm{a}}$, which made the tails readily visible on the thermograms. In contrast, the tails of all mice were strongly vasoconstricted at a low $T_{\mathrm{a}}$ of $30.0^{\circ} \mathrm{C}$ (Fig. $4 \mathrm{H}$ ). Under these conditions, $T_{\mathrm{sk}}$ was approaching $T_{\mathrm{a}}$, which made the tails invisible on the thermograms. At all $T_{\mathrm{a}} \mathrm{s}$ between 30.0 and $35.0^{\circ} \mathrm{C}$, the extent of tail skin vasodilation/vasoconstriction varied between the animals, and $\operatorname{Trp} v 1^{-/-}$mice always showed stronger vasoconstriction than their $\operatorname{Trp} v 1^{+/+}$counterparts. At some $T_{\mathrm{a}} \mathrm{s}$ (e.g., $32.0^{\circ} \mathrm{C}$ ) (Fig. $4 E$ ), the tails of all $\operatorname{Tr} p v 1 \mathrm{KO}$ mice were invisible $\left(T_{\text {sk }}\right.$ close to $T_{\mathrm{a}}$ ), whereas the tails of all controls were readily visible $\left(T_{\text {sk }}>T_{\mathrm{a}}\right)$. In this case the intergenotype difference in $T_{\mathrm{sk}}$ exceeded $4^{\circ} \mathrm{C}$, which cannot be explained by a small difference in the deep $T_{\mathrm{b}}$ and indicates unequivocally a difference in the tail skin vasomotor tone. All control mice showed profound tail skin vasoconstriction at $T_{\mathrm{a}}<30.5^{\circ} \mathrm{C}$ and profound vasodilation at $T_{\mathrm{a}}>32.0^{\circ} \mathrm{C}$, thus suggesting that their TNZ in the setup studied was somewhere between 30.5 and $32.0^{\circ} \mathrm{C}$. In the same setup, all Trpv1 $\mathrm{KO}$ mice showed profound tail skin vasoconstriction at $T_{\mathrm{a}}<31.5^{\circ} \mathrm{C}$ and profound vasodilation at $T_{\mathrm{a}}>33.5^{\circ} \mathrm{C}$, thus suggesting that their TNZ in this setup was somewhere between 31.5 and $33.5^{\circ} \mathrm{C}$. To assess the extent of vasodilation quantitatively, we determined the optical density value for each tail image shown in Figure 4. An analysis of these values (two-way ANOVA) showed that the effect of the genotype was highly significant ( $p=$ $0.0001)$. Hence, Trpv1 KO mice have a higher TNZ than wildtype mice.
Positions 1, 3, and 5: $\operatorname{Trpv1}{ }^{-1-}$

Positions 2, 4, and 6: $\bigcirc \operatorname{Trpv1} 1^{+/+}$
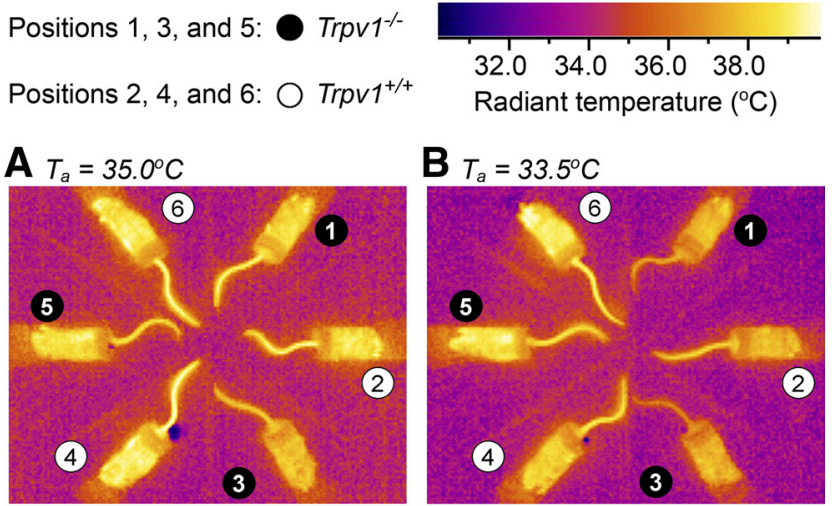

C $T_{a}=33.0^{\circ} \mathrm{C}$

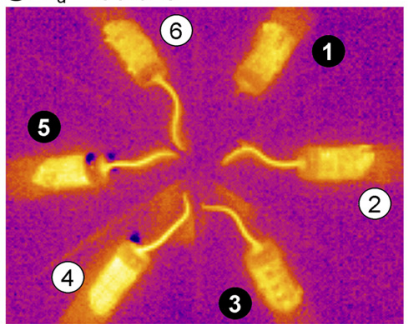

D $T_{a}=32.5^{\circ} \mathrm{C}$
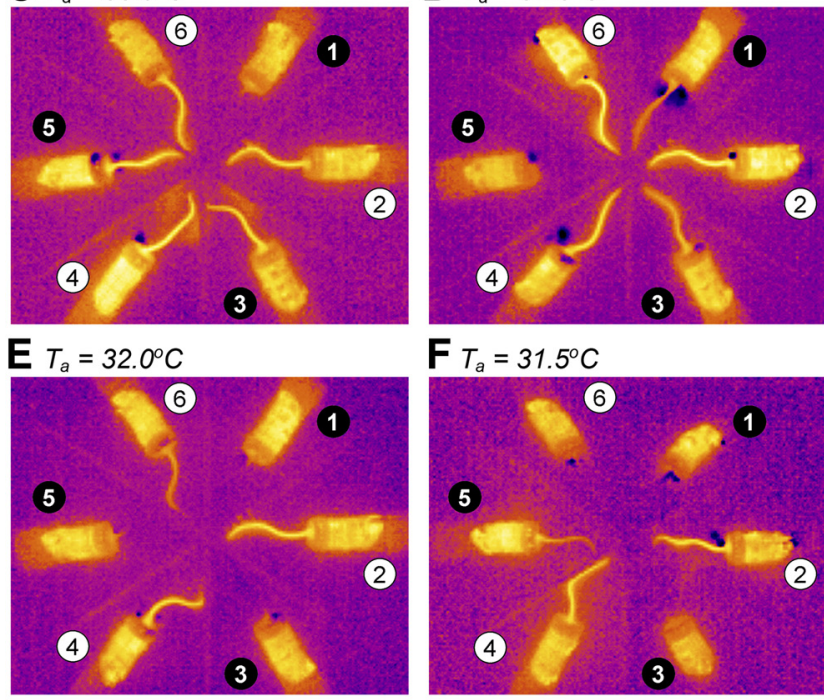

G $T_{a}=30.5^{\circ} \mathrm{C}$

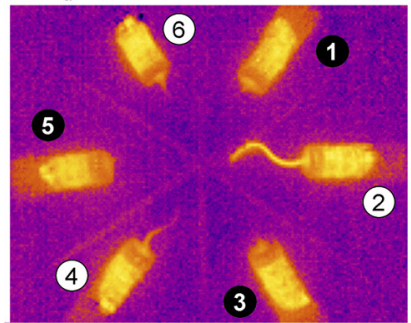

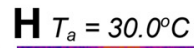

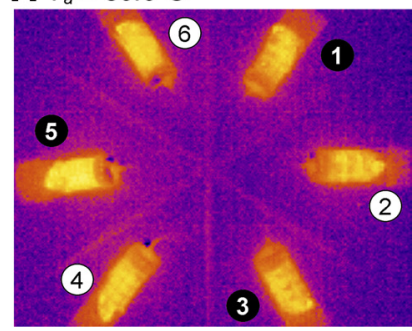

Figure 4. Trpv1 $\mathrm{K} 0$ mice have a higher TNZ. Three $\operatorname{Trpv} 1 \mathrm{KO}$ and three control mice in their confiners were situated in the thermocouple setup as slices of a pizza pie, so that their tails pointed to the center of the "pizza." In this setup, infrared thermograms were taken at different $T_{\mathrm{a}} \mathrm{s}: 35.0(\boldsymbol{A}), 33.5(\boldsymbol{B}), 33.0(\boldsymbol{C}), 32.5(\boldsymbol{D}), 32.0(\boldsymbol{E}), 31.5(\boldsymbol{F}), 30.5(\boldsymbol{G})$, and $30.0^{\circ} \mathrm{C}(\boldsymbol{H})$. It is known (see Results) that tails of rats and mice exhibit continuous skin vasodilation above the TNZ and continuous skin vasoconstriction below the TNZ. Note that all tails are clearly visible (vasodilated) at the highest $T_{a}(\boldsymbol{A})$ and completely invisible (vasoconstricted) at the lowest $T_{\mathrm{a}}(\boldsymbol{H})$. As $T_{\mathrm{a}}$ decreases (from $\boldsymbol{B}$ to $\boldsymbol{G}$ ), Trpv1 K0 mice become vasoconstricted faster than wild-type mice. Because within the TNZ, the tone of tail skin vasculature constantly changes between moderate constriction and moderate dilation and exhibits a high intrasubject and intersubject variation (Romanovsky et al., 2002), we conclude that the TNZ in this setup is $31.5-33.5^{\circ} \mathrm{C}$ for $\operatorname{Trpv} 1 \mathrm{KO}$ mice and $30.5-32.0^{\circ} \mathrm{C}$ for the controls.

\section{The thermoregulatory response of $\operatorname{Trpv1} \mathrm{KO}$ mice to heat} is unaltered

After we found that tail skin vasomotor tone was altered in $\operatorname{Trp} v 1$ KO mice (Figs. 3B, 4), we studied the thermoregulatory response of these mice to ambient heating. To reveal even a small deficiency in heat defenses, we used a severe heat exposure model that results in a $\sim 3^{\circ} \mathrm{C}$ rise in deep $T_{\mathrm{b}}$. When exposed to heat, the mice 
of both genotypes (Trpv1 $1^{-/-}$and $\left.\operatorname{Tr} p v 1^{+/+}\right)$responded with rapid, near-maximal tail skin vasodilation with $T_{\text {sk }}$ approaching $40^{\circ} \mathrm{C}$ (Fig. 5A). Neither the $T_{\text {sk }}$ response nor the $T_{\mathrm{c}}$ response differed between the genotypes. Hence, despite the strong attenuation of heat-induced tail skin vasodilation reported in rats desensitized pharmacologically with TRPV1 agonists (for reviews, see Hori, 1984; Romanovsky et al., 2009), Trpv1 KO mice are fully capable of increasing heat loss through their tails and defending their deep $T_{\mathrm{b}}$ against heat. These results confirm the earlier observations by Szelényi et al. (2004) and Iida et al. (2005) showing that autonomic heat defenses of Trpv1 KO mice are not compromised.

Trpv1 KO mice can maintain cold-induced thermogenesis longer than genetically unaltered controls

To reveal even a small deficiency in cold defenses, we used a severe cold exposure model that results in a pronounced drop in deep $T_{\mathrm{b}}$. When exposed to cold in this model, the mice of both genotypes responded with tail skin vasoconstriction (a decrease in $T_{\text {sk }}$ ) and cold-induced thermogenesis (an increase in $V_{\mathrm{O}_{2}}$ ), but despite these cold-defense responses, their $T_{c}$ decreased by $>14^{\circ} \mathrm{C}$ (Fig. $5 \mathrm{~B}$ ). The response dynamics differed between the two genotypes. Whereas $V_{\mathrm{O}_{2}}$ of $\operatorname{Trp} v 1 \mathrm{KO}$ mice reached a plateau at $\sim 60$ min after the beginning of cold exposure and was then maintained at this level until the end of the experiment (150 min), $V_{\mathrm{O}_{2}}$ of the controls reached the same level, but then started decreasing at $\sim 100 \mathrm{~min}(p<0.0001)$ and caused a corresponding decrease in $T_{\mathrm{c}}(p<0.0001)$. These data show that even though Trpv1 KO mice have a lower metabolic rate under basal conditions, they can maintain cold-induced thermogenesis for a somewhat longer period of time than genetically unaltered mice. An earlier study by Iida et al. (2005) did not find a difference in the thermoregulatory response of $\operatorname{Tr} p v 1 \mathrm{KO}$ mice to cold, but the authors used a much milder cold exposure. The combination of physical factors affecting the heat exchange between an animal and its environment ( $T_{\mathrm{a}}$, air humidity, air velocity, etc.) together with the use of confinement in our experimental paradigm resulted in a much greater decrease in deep $T_{\mathrm{b}}$ of the wild-type mice than that observed in the study by Iida et al. (2005): $14.2 \pm 1.1$ versus $1.2 \pm 0.5^{\circ} \mathrm{C}$. On the other hand, our results agree with those of Motter and Ahern (2008), who used stronger cooling (a $2.0-3.4^{\circ} \mathrm{C}$ decrease in $T_{\mathrm{b}}$ of wild-type mice) than Iida et al. (2005) and found that $\operatorname{Trp} v 1 \mathrm{KO}$ mice could defend their deep $T_{\mathrm{b}}$ against environmental cold somewhat better than their wild-type counterparts. Whether the slightly enhanced thermogenic capacity of the Trpv1 KO mice observed in this experiment was due to nonshivering or shivering thermogenesis, or both, is unknown.

\section{Peripheral administration of an exogenous TRPV1 agonist decreases stress-induced locomotion via an action on the TRPV1 channel}

After finding that Trpv1 KO mice were hyperactive (Fig. 3), we tested whether RTX, an ultrapotent exogenous TRPV1 agonist, decreases the gross locomotor activity. For this, we administered RTX intraperitoneally to $\operatorname{Tr} p v 1^{-/-}$mice with a C57BL/6x129 genetic background and to two strains of $\operatorname{Tr} p v 1^{+/+}$mice, C57BL/ 6x129 and C57BL/6. These experiments (and all experiments to follow) were performed in the telemetry setup. Because the expected effect of RTX was a decrease in the gross locomotor activity, RTX or its vehicle was administered acutely by briefly restricting the animal and pricking it with a needle (see Materials and Methods, Drugs and drug administration). In this paradigm, the handling and needle pricking associated with drug administration elevate the low activity typical for habituated mice during

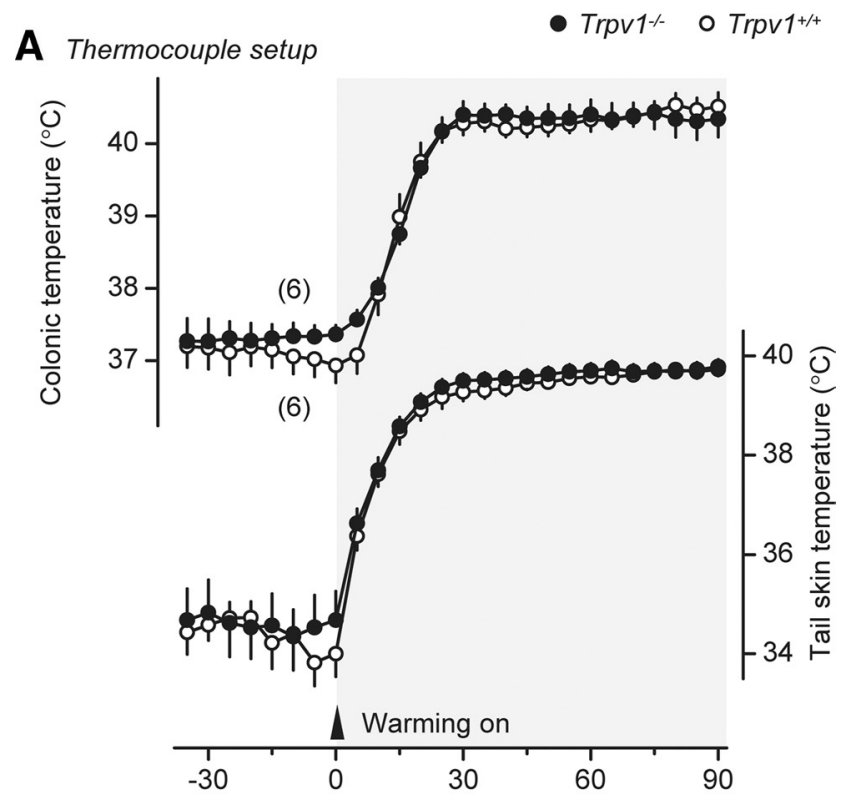

B Respirometry setup

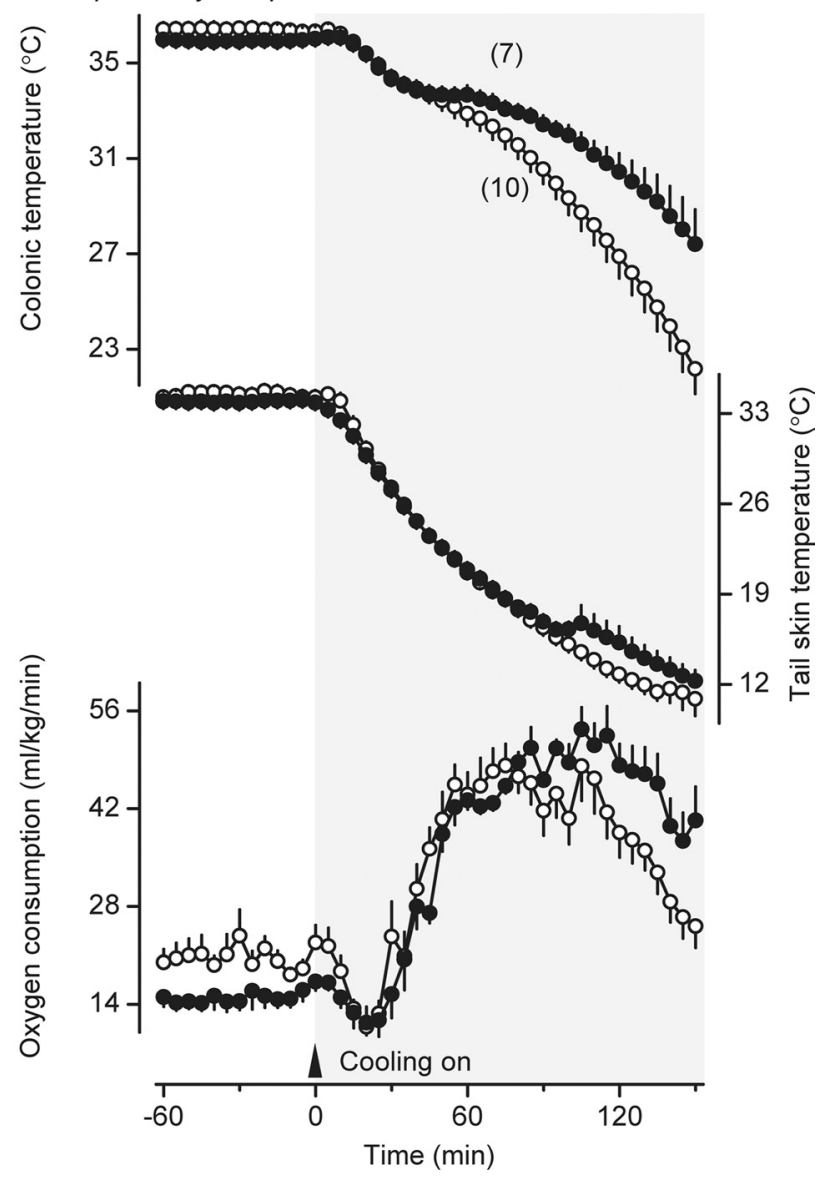

Figure 5. Thermoeffector and deep $T_{\mathrm{b}}$ responses of $\operatorname{Trpv} 1 \mathrm{~K} 0$ and genetically unaltered confined mice to severe heat exposure $(\boldsymbol{A})$ and severe cold exposure $(\boldsymbol{B})$. During heat exposure, $T_{\text {a }}$ was first raised from $31.0^{\circ} \mathrm{C}$ to $39.0^{\circ} \mathrm{C}$ at a rate of $\sim 0.3^{\circ} \mathrm{C} / \mathrm{min}$ and then maintained at $39.0^{\circ} \mathrm{C}$ until the end of the experiment. Deep $T_{\mathrm{b}}$ (colonic) and tail skin vasodilation $\left(T_{\mathrm{sk}}\right)$ responses of the two genotypes to heat exposure were identical. During cold exposure, $T_{\mathrm{a}}$ was decreased from $33.0^{\circ} \mathrm{C}$ to $5.0^{\circ} \mathrm{C}$ at a mean rate of $0.2^{\circ} \mathrm{C} / \mathrm{min}$. In response to cold exposure, Trpv1 $\mathrm{K} 0$ mice maintain an increased thermogenesis $\left(V_{\mathrm{O}_{2}}\right)$ longer, thus better defending their $T_{\mathrm{b}}$ against severe cold. 
the light phase. The well known ability of RTX to decrease $T_{\mathrm{b}}$ (for review, see Romanovsky et al., 2009) was also evaluated, and to allow the animals to readily decrease their $T_{\mathrm{b}}$, the experiments were performed at a slightly subneutral $T_{\mathrm{a}}$ of $26.0^{\circ} \mathrm{C}$. The administration of the vehicle caused moderate hyperactivity and typical stress hyperthermia in all genotypes tested (Fig. 6). RTX (200 ng/kg, i.p.) blocked both the hyperactivity and hyperthermia responses in $\operatorname{Trp} v 1^{+/+} \mathrm{C} 57 \mathrm{BL} / 6$ and C57BL/6x129 mice $(p<0.0001$ for both responses in both strains) (Fig. 6A,B), even though the low dose of RTX used did not cause hypothermia. These results agree with studies showing that capsaicin, another exogenous TRPV1 agonist, decreases locomotor activity in rats and mice (Di Marzo et al., 2000, 2001; Proulx et al., 2005; Lee et al., 2006), and that both RTX (at higher doses) and capsaicin cause hypothermia in many mammalian species [for review, see Romanovsky et al. (2009)]. In the present study, the same dose of RTX that caused the anti-hyperkinetic and anti-hyperthermic effects in the control mice did not affect the stress-induced changes in $T_{\mathrm{ab}}$ or locomotor activity in Trpv1 KO mice (Fig. 6C). These results indicate that peripherally administered RTX decreases stress-induced locomotor activity and hyperthermia in mice by acting on TRPV1 channels. It was important to demonstrate an involvement of TRPV1 channels, because some effects of exogenous TRPV1 agonists (Lundbaek et al., 2005), including thermoregulatory effects (Dogan et al., 2004; Nikami et al., 2008), are not TRPV1 mediated.

\section{Peripheral administration of an endogenous TRPV1 agonist decreases stress-induced locomotion via an action on the TRPV1 channel}

We then tested whether AEA, an endocannabinoid with a full agonistic activity against TRPV1, affects $T_{\mathrm{ab}}$ and stress-induced locomotion in a way similar to RTX. In this experiment, the acute intraperitoneal injection of the vehicle resulted in an increase in the locomotor activity, similar to those shown in Figure 6, but did not cause stress hyperthermia. The blunted effect of stress on $T_{\mathrm{ab}}$ was probably due to the fact that a large volume of a roomtemperature vehicle was used to deliver the high dose of AEA: 30 $\mathrm{ml} / \mathrm{kg}$ ( $\sim 0.9 \mathrm{ml}$ per mouse) in this experiment (Fig. 7) as compared to $3.3 \mathrm{ml} / \mathrm{kg}$ ( $\sim 0.1 \mathrm{ml}$ per mouse) in the RTX experiment (Fig. 6). As compared to its vehicle, AEA (15 mg/kg, i.p.) significantly decreased $T_{\mathrm{ab}}$ and strongly attenuated locomotor activity (suppressed stress hyperkinesis) in $\operatorname{Trp} v 1^{+/+}$mice of both strains: C57BL/6 $\left(p<0.0001\right.$ for $T_{\mathrm{ab}} ; p<0.05$ for locomotor activity) (Fig. 7A) and C57BL/6x129 ( $p<0.05$ for $T_{\mathrm{ab}} ; p<0.01$ for locomotor activity) (Fig. $7 B$ ). These results agree with the reported hypothermic and hypokinetic effects of AEA, administered to rats and mice at high doses (Crawley et al., 1993; Fride and Mechoulam, 1993; Smith et al., 1994; Adams et al., 1998; Watanabe et al., 1999; Wiley et al., 2006; Wise et al., 2007). How-

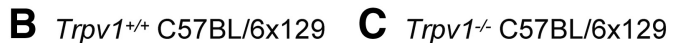

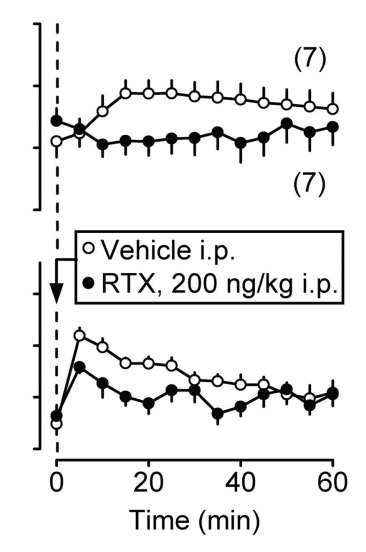

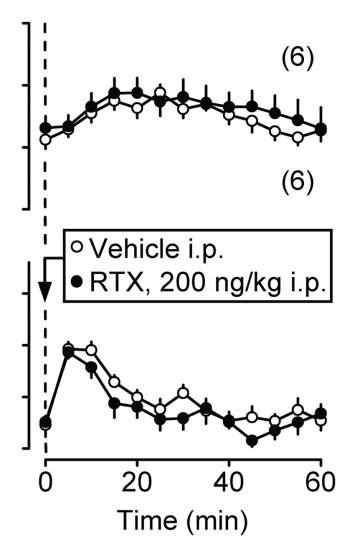

(6)
$(6)$

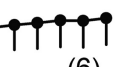

(6)

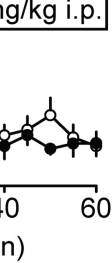

Figure 6. Intraperitoneal RTX (200 ng/kg) attenuates the injection-induced hyperthermia and hyperkinesis in $\operatorname{Trpv} 1^{+/+}$mice of two strains, C57BL/6 $(\boldsymbol{A})$ and C57BL/6x129 (B), but not in Trpv1 ${ }^{-1-}$ C57BL/6x129 mice (C). These experiments and those

A Trpv1+/+ C57BL/6

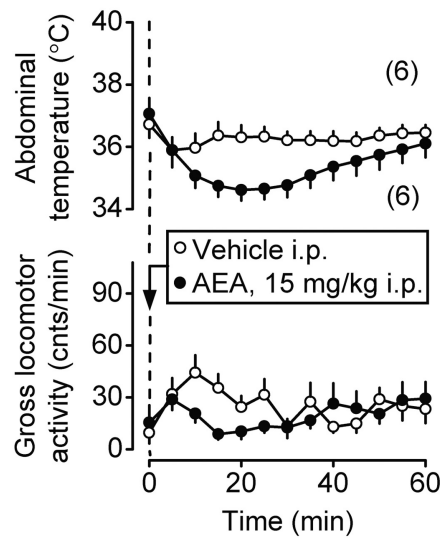

B Trpv1+/+ C57BL/6x129

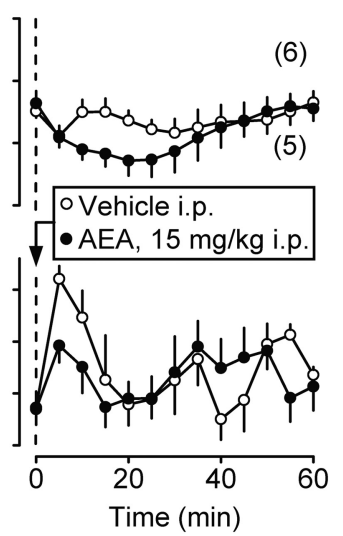

Trpv1 1 C57BL/6x129

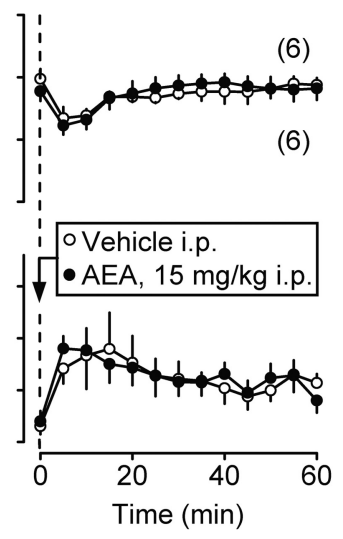

Figure 7. Intraperitoneal AEA $(15 \mathrm{mg} / \mathrm{kg})$ causes hypothermia and attenuates the injection-induced hyperkinesis in $\operatorname{Trpv} 1^{+/+}$

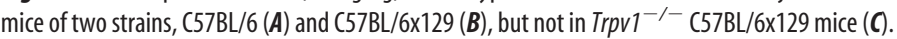

ever, none of these effects occurred when AEA was injected in Trpv1 $1^{-1-}$ C57BL/6x129 mice (Fig. 7C). Even though AEA also acts as a full agonist at the cannabinoid-1 receptor (Vogel et al., 1993) and as a partial agonist at the cannabinoid-2 receptor (Gonsiorek et al., 2000), the complete absence of both $T_{\mathrm{b}}$ decreasing and activity-decreasing effects of AEA in Trpv1 KO mice shows that cannabinoid receptors do not mediate the effects studied. This is the first observation showing directly that AEA suppresses deep $T_{\mathrm{b}}$ and locomotor activity by acting on the TRPV1 channel.

Peripheral administration of a selective TRPV1 antagonist produces hyperkinesis via an action on the TRPV1 channel Next, we studied the effect of AMG0347, a TRPV1 antagonist, on deep $T_{\mathrm{b}}$ and locomotor activity of $\operatorname{Trp} v 1^{-/-}$and $\operatorname{Trp} v 1^{+/+}$ C57BL/6x129 mice. Based on the results with TRPV1 agonists (Figs. 6, 7), we expected the antagonist to cause an increase in the locomotor activity. To study the expected increase, we avoided inducing stress hyperkinesis and infused AMG0347 or its vehicle in a nonstressful manner, through a preimplanted intraperitoneal catheter, from outside of the climatic chamber. Because the expected thermal effect was hyperthermia (Steiner et al., 2007; Garami et al., 2010), these experiments were conducted at $T_{\mathrm{a}}$ of 
A $\operatorname{Trpv}^{1+/+} \mathrm{C} 57 \mathrm{BL} / 6 \times 129$

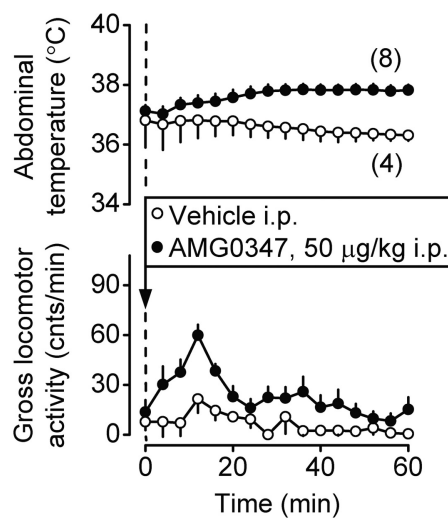

B $\operatorname{Trpv1}$ 1 C57BL/6x129

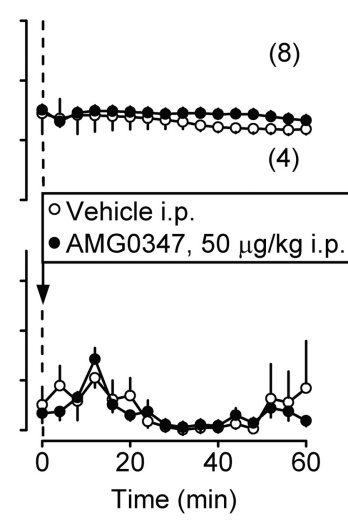

Figure 8. Intraperitoneal AMG0347 (50 $\mu \mathrm{g} / \mathrm{kg}$ ) causes hyperthermia and locomotor hyperactivity in wild-type mice $(\boldsymbol{A})$ but not in $\operatorname{Trpv} 1 \mathrm{KO}$ mice $(\boldsymbol{B})$. These experiments were performed in the telemetry setup at a neutral $T_{\mathrm{a}}$ of $31.0^{\circ} \mathrm{C}$.

$31.0^{\circ} \mathrm{C}$, which is neutral for both $\operatorname{Trp} v 1 \mathrm{KO}$ and control mice in the telemetry setup (Table 1). As compared to its vehicle, AMG0347 (50 $\mu \mathrm{g} / \mathrm{kg}$, i.p.) caused hyperthermia and hyperkinesis in $\operatorname{Tr} p v 1^{+/+}$mice $(p<0.0001$ for both) (Fig. $8 A)$. Whereas it is well known that TRPV1 antagonists cause hyperthermia (for reviews, see Gavva, 2008; Romanovsky et al., 2009), the observed increase in the locomotor activity was an unexpected finding, because earlier studies in rats with several TRPV1 antagonists reported no changes in the locomotor activity (Gavva et al., 2005; Cui et al., 2006; Drizin et al., 2006; Mills et al., 2008). However, the TRPV1 antagonists in all these studies were administered in a stressful way (often as intragastric gavage), and the resultant stress-induced hyperkinesis could have masked the short-lived and modest increase in the locomotor activity seen in the present study. The same dose of AMG0347 that caused hyperthermia and hyperkinesis in the control mice affected neither $T_{\mathrm{ab}}$ nor gross locomotor activity in Trpv1 KO mice (Fig. 8B). Whereas it has been shown in our previous studies that TRPV1 antagonists cause hyperthermia by acting on TRPV1 channels (Steiner et al., 2007; Garami et al., 2010), the present study is the first to demonstrate a hyperkinetic effect for AMG0347 and to show that this effect occurs due to an action at the TRPV1 channel.

\section{A TRPV1 agonist suppresses stress-induced locomotion by acting outside the brain}

We then attempted to determine whether the anti-hyperkinetic response to intraperitoneal RTX (Fig. 6) occurs due to an action inside or outside the brain. A very low dose of RTX, $20 \mathrm{ng} / \mathrm{kg}$, was used in this experiment and administered either intraperitoneally or into the lateral brain ventricle. When administered intraperitoneally, this dose attenuated the injection-induced hyperthermia and the locomotor response ( $p<0.0001$ for both) (Fig. 9A). However, the same dose of RTX administered intracerebroventricularly affected neither parameter (Fig. 9B). These data suggest that RTX affects locomotion by acting outside the blood-brain barrier. It should be noted that the low doses of RTX used in the present study, $20 \mathrm{ng} / \mathrm{kg}$ (Fig. 9) and $200 \mathrm{ng} / \mathrm{kg}$ (Fig. 6), did not cause a typical hypothermic response, but did decrease the injection-associated rise in $T_{\mathrm{b}}$. Such an action on $T_{\mathrm{b}}$ is likely to be secondary to the decrease in locomotor activity. At higher doses, RTX readily causes marked hypothermia (de Vries and Blumberg, 1989; Romanovsky et al., 2009), and the marked hypother-
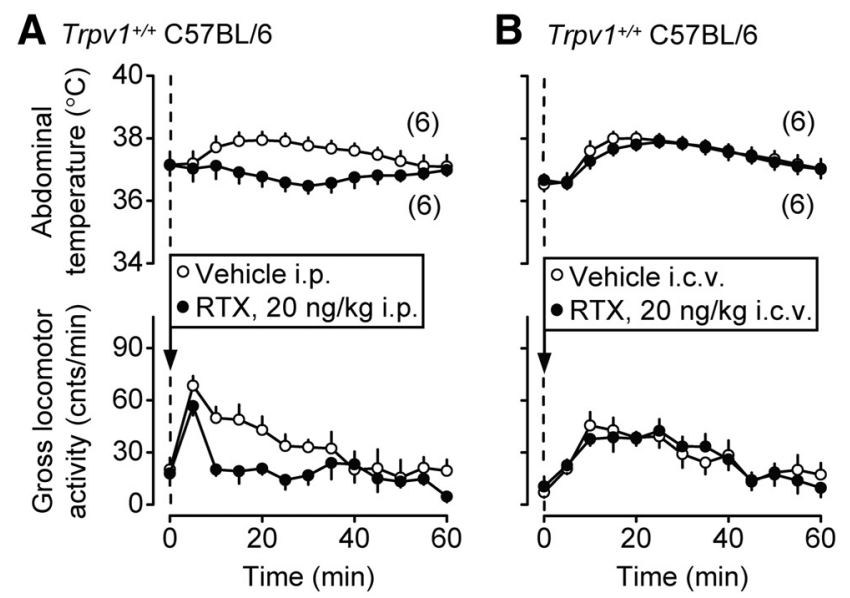

Figure 9. The intraperitoneal $(\boldsymbol{A})$, but not intracerebroventricular $(\boldsymbol{B})$, administration of RTX at a dose of $20 \mathrm{ng} / \mathrm{kg}$ attenuates the injection-induced hyperthermia and hyperkinesis in Trpv $1^{+/+}$C57BL/6 mice.

mic response to RTX is thought to be due to a central, rather than peripheral, action [for review, see Romanovsky et al. (2009)].

\section{Aged Trpv1 KO mice are heavier than genetically} unaltered controls

As a side finding, we noticed that, with age, Trpv1 $\mathrm{KO}$ mice of both sexes became heavier than their $\operatorname{Tr} p v 1^{+/+}$counterparts (Fig. $10)$. For example, at the age of 8 months, the body mass of the male Trpv1 KO mice was $14 \%$ higher than that of the agematched male controls: $49 \pm 1$ versus $43 \pm 1 \mathrm{~g}(p<0.0001)$. The two heaviest mice in our colony were Trpv1 KO males, who had a body mass of $59 \mathrm{~g}$ (at the age of 8 months) and $58 \mathrm{~g}$ (at the age of 14 months). By the time we discovered that aged Trpv1 KO mice were significantly heavier than their wild-type counterparts, Amgen had terminated its colony, which made obtaining any additional measures (the amount and distribution of fat, blood lipids) impossible. Even though we did not measure the amount of fat, the aged $\operatorname{Trp} v 1 \mathrm{KO}$ mice looked obese, rather than proportionally large. They had larger bellies, a symptom consistent with accumulation of visceral fat, a generally accepted hallmark of aging (Huffman and Barzilai, 2009). We also noticed both a large amount of visceral fat and a thick layer of subcutaneous fat while performing surgeries on older Trpv1 KO mice for a different study (S. P. Wanner and A. A. Romanovsky, unpublished observations). The observed association of hyperactivity (recorded at a younger age) with overweight (recorded at an older age) seems paradoxical, but a similar relationship was reported for a group of healthy humans: those individuals who were more physically active when they were young showed a higher mass gain with age (Westerterp and Plasqui, 2009). Based on the present observation, it is tempting to speculate that TRPV1 channels protect from aging-associated obesity. From the thermoregulatory point of view, the increased body mass found in aged Trpv1 KO mice may have an insulating role, similar to that played by subcutaneous fat in animals living in cold climates (Blix and Steen, 1979).

\section{Discussion}

In agreement with previous studies (Szelényi et al., 2004; Iida et al., 2005), we have found no profound alterations in basal $T_{\mathrm{b}}$ in Trpv1 KO mice (Fig. 2). We have also confirmed that, compared to their $\operatorname{Tr} p v 1^{+/+}$counterparts, $\operatorname{Tr} p v 1^{-/-}$mice have a slightly higher magnitude of circadian fluctuations in $T_{\mathrm{b}}$. The main thermoregulatory abnormality of $\operatorname{Tr} p v 1 \mathrm{KO}$ mice appears to be not an 

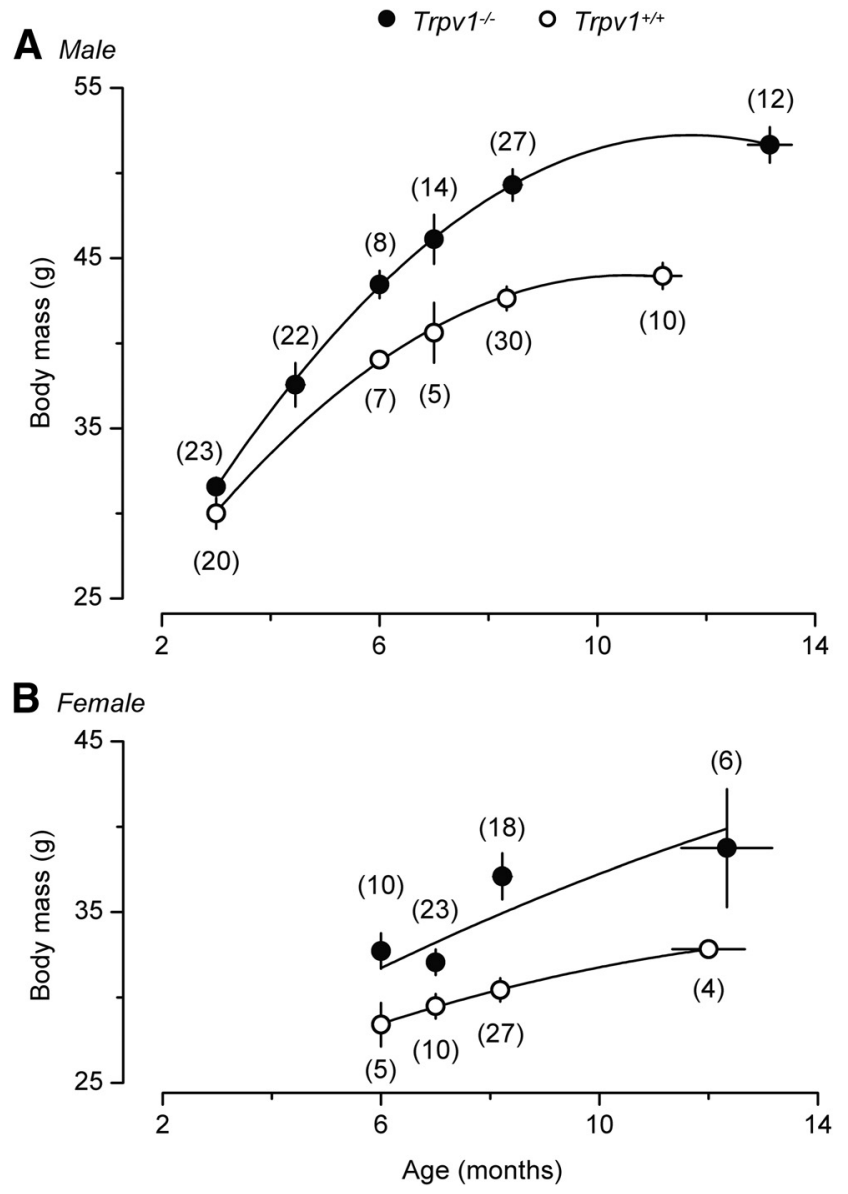

Figure 10. With age, both male $(\boldsymbol{A})$ and female (B) Trpv1 K0 mice become heavier than their age-matched controls.

altered level of $T_{\mathrm{b}}$, but a different pattern of thermoeffectors used to regulate $T_{\mathrm{b}}$ under various thermal, housing, and restraint conditions. Trpv1 KO mice were consistently hypometabolic (had a lower $V_{\mathrm{O}_{2}}$ ) and preferred a lower $T_{\mathrm{a}}$ than controls (Fig. 3). These thermoeffector changes tend to decrease $T_{\mathrm{b}}$. At the same time, the $\mathrm{KO}$ mice expressed two thermoeffector activities aimed at increasing $T_{\mathrm{b}}$. First, they had more pronounced tail skin vasoconstriction (Fig. $3 B$ ) and, in agreement with this, had a higher TNZ (Fig. 4). Second, they expressed strong hyperkinesis with the average locomotion velocity during the second half of the inactive phase exceeding that of wild-type mice during the active phase (Fig. $3 A$ ).

This finding of increased locomotor activity of Trp $1 \mathrm{KO}$ mice deserves a separate discussion, as it seems to contradict several studies showing that the deletion of the Trpv1 gene causes no changes in locomotion (Caterina et al., 2000; Davis et al., 2000; Marsch et al., 2007). However, all these studies used much shorter observation periods, sometimes as short as $15 \mathrm{~min}$. Furthermore, even though these studies found no statistically significant differences in the locomotor activity of Trpv1 KO mice, some of them showed strong tendencies that were in agreement with the present results. For example, Davis et al. (2000) found that Trpv1 KO mice tended to have higher scores in several activity tests. In the hole board test for exploratory behavior, the activity of Trpv1 KO mice exceeded that of wild-type mice by $92 \%$ $(p=0.12)$. An increased activity of Trpv1 KO mice was also observed by Marsch et al. (2007) in several tests for anxietyrelated behaviors. In these tests, Trpv1 KO mice adapted to experimental conditions faster and expressed exploratory behav- iors associated with a higher locomotor activity. However, other studies have found no involvement of TRPV1 channels in anxiety behaviors (Bitencourt et al., 2008; Panlilio et al., 2009). The increased spontaneous locomotion observed in our study is also unlikely to be due to changes in anxiety or exploratory behavior, because the mice were extensively adapted to experimental conditions and observed over long periods of time. Whether the increased locomotion relates to changes in the sleep pattern is unknown, but TRPV1 antagonists do not seem to affect sleep (Takeda et al., 2008).

Because their autonomic thermoregulatory responses showed no attenuation in our study and in studies by others (Szelényi et al., 2004; Iida et al., 2005; Motter and Ahern, 2008), we directed our attention to the behavioral responses: the selection of $T_{\mathrm{a}}$, which is the classic example of thermoregulatory behavior, and the gross locomotor activity, which is viewed by many authors as a thermoregulatory effector in small rodents. In the thermogradient apparatus, we saw that $\operatorname{Tr} p v 1 \mathrm{KO}$ mice preferred a lower $T_{\mathrm{a}}$ and were hyperactive as compared to the controls (Fig. 3). Similar to how humans prefer to exercise in a cooler environment, experimental rodents select a lower $T_{\mathrm{a}}$ when their activity is higher. Such an adjustment of the preferred $T_{\mathrm{a}}$ accompanies the increase in the locomotor activity of rats (Gordon, 1994) and mice (Fig. 3) at the transition from the inactive (light) phase to the active (dark) phase. A similar adjustment accompanies the exploratory behavior of rats in a thermogradient apparatus when the animals are not adapted to the apparatus [for discussion, see Almeida et al. (2006)]. Having excluded profound deficiencies in the two major autonomic effectors directly (Fig. 5) and knowing that a decrease in the thermopreferendum often occurs secondarily to an increase in locomotor activity, we are tempted to speculate that the increased locomotion may be one of the "primary" symptoms of the Trpv1 KO phenotype. We then focused the second part of the study on locomotor activity.

We asked whether pharmacological manipulations with the activity of TRPV1 channels would affect the locomotor activity (and also $T_{\mathrm{b}}$ ). First, we showed that RTX (an exogenous TRPV1 agonist) and AEA (an endogenous TRPV1 agonist) both attenuated stress-induced hyperactivity in $\operatorname{Tr} p v 1^{+/+}$mice of two strains (Figs. 6, 7). This effect agrees well with the reported hypokinetic action of these and other TRPV1 agonists in several different tests (Di Marzo et al., 2001; Proulx et al., 2005; Wiley et al., 2006; Wise et al., 2007). Next, we studied the responses to RTX and AEA in Trpv1 KO mice. By showing that the locomotor activity response was unaffected by these TRPV1 agonists in Trpv1 KO mice, we have confirmed that the anti-hyperkinetic effect of either agonist occurs via an action on TRPV1. This is in agreement with the finding that the AEA-induced decrease in locomotor activity of rats is blocked by TRPV1 antagonists (de Lago et al., 2004; Lee et al., 2006; Tzavara et al., 2006). In the next experiment, we used AMG0347, a highly potent and selective TRPV1 antagonist. In addition to causing the well characterized hyperthermic effect (Steiner et al., 2007; Garami et al., 2010), a nonstressful intraperitoneal administration of AMG0347 also increased the locomotor activity in Trpv1 $1^{+/+}$mice (Fig. 8). However, AMG0347 did not increase locomotion in Trpv1 KO mice, thus indicating that the hyperkinetic effect of AMG0347 occurs via an action on TRPV1. Hence, our results with RTX, AEA, and AMG0347 support the hypothesis that TRPV1 channels tonically suppress the general locomotor activity.

We then asked whether the TRPV1 channels involved are located inside or outside the brain. To answer this question, we injected a very low dose of RTX (20 ng/ $\mathrm{kg}$ ) either intraperitoneally or into the lateral cerebral ventricle. The intraperitoneal ad- 
ministration was effective in decreasing the injection-associated locomotion, whereas the intracerebroventricular administration was not (Fig. 9), thus suggesting that RTX causes its antihyperkinetic activity by acting outside the blood-brain barrier. Such a peripheral action agrees with the predominant location of TRPV1 channels on polymodal sensory neurons in the dorsalroot and nodose ganglia (Szallasi et al., 1995; Caterina et al., 1997; Tominaga et al., 1998). These neurons are activated by a variety of stimuli and are thought to modulate a wide array of autonomic and behavioral functions (Caterina and Julius, 2001; Inoue et al., 2006; Nilius et al., 2007; Szallasi et al., 2007; Sharif-Naeini et al., 2008; Romanovsky et al., 2009). Tonic activation of peripheral TRPV1 channels has been shown to inhibit thermogenesis and heat retention in the study by Steiner et al. (2007), to modulate spinal locomotor networks in the study by Mandadi et al. (2009), and to inhibit the general locomotor activity in the present work.

As a side observation, we have found that, with age, Trpv1 KO mice of either sex (maintained on a regular diet) become heavier than their wild-type counterparts (Fig. 10). This observation seems to contradict studies by Davis et al. (2000), Rong et al. (2004), and Zhang et al. (2007), who found no changes in the body mass of Trpv1 KO mice compared to controls, when maintained on a regular or high-fat diet. It also contradicts the study by Motter and Ahern (2008), in which Trpv1 KO mice were found less prone than wild-type controls to become obese on a high-fat diet. However, all abovementioned studies used young mice with the body mass in a 10-30 g range (on a regular diet). In this body mass range, the intergenotype difference in our study was also small, but with age (we observed the mice up to the age of 14 months), the difference increased (Fig. 10). Interestingly, the obesity-protective role of TRPV1 channels has been proposed (Zhang et al., 2007; Suri and Szallasi, 2008) and is supported by two lines of evidence. First, Zhang et al. (2007) detected TRPV1 channels in preadipocytes, as well as in visceral adipose tissue from mice and humans. These authors demonstrated TRPV1 downregulation during regular adipogenesis and a reduced TRPV1 expression in visceral adipose tissue from obese mice and humans. Second, a long-term administration of capsaicin or capsinoids (nonpungent, capsaicin-related TRPV1 agonists) has been repeatedly shown to suppress visceral fat accumulation, induce thermogenesis, and prevent an increase in the body mass in laboratory animals and humans (Kawabata et al., 2006; Zhang et al., 2007; Snitker et al., 2009). Further studies of the role of the TRPV1 channel in obesity seem warranted.

In conclusion, the first part of the present study shows that Trpv1 KO mice possess a distinct thermoregulatory phenotype, which includes hypometabolism, enhanced skin vasoconstriction, preference for a lower $T_{\mathrm{a}}$, and an increased locomotor activity. The second part of our study shows that TRPV1 agonists and antagonists decrease and increase, respectively, the locomotor activity by acting on TRPV1 channels. For agonists, their effect on locomotion is due to an action outside the brain. We propose that TRPV1-mediated signals from the periphery tonically suppress general locomotor activity. Whether such suppression occurs due to a direct action on the locomotor system or indirectly (e.g., by affecting motivation or vigilance state) is a topic for future studies. The nature of the TRPV1-mediated signals that suppress locomotion also remains to be elucidated.

\section{Notes}

The curves of gross locomotor activity measured simultaneously by intraperitoneal telemetry probes and by external motion detectors in mice treated with different drugs are presented in supplemental
Figure 1 posted at http://www.feverlab.net/pages/publicationpdfs/ supplementJN2011.pdf. This material has not been peer reviewed.

\section{References}

Adams IB, Compton DR, Martin BR (1998) Assessment of anandamide interaction with the cannabinoid brain receptor: SR 141716A antagonism studies in mice and autoradiographic analysis of receptor binding in rat brain. J Pharmacol Exp Ther 284:1209-1217.

Almeida MC, Steiner AA, Branco LG, Romanovsky AA (2006) Cold-seeking behavior as a thermoregulatory strategy in systemic inflammation. Eur J Neurosci 23:3359-3367.

Berkley R, Jacobson E (1992) Peppers: a cookbook. New York: Simon and Schuster.

Bitencourt RM, Pamplona FA, Takahashi RN (2008) Facilitation of contextual fear memory extinction and anti-anxiogenic effects of AM404 and cannabidiol in conditioned rats. Eur Neuropsychopharmacol 18:849-859.

Blix AS, Steen JB (1979) Temperature regulation in newborn polar homeotherms. Physiol Rev 59:285-304.

Brown D, Livesey G, Dauncey MJ (1991) Influence of mild cold on the components of 24 hour thermogenesis in rats. J Physiol 441:137-154.

Caterina MJ, Julius D (2001) The vanilloid receptor: a molecular gateway to the pain pathway. Annu Rev Neurosci 24:487-517.

Caterina MJ, Schumacher MA, Tominaga M, Rosen TA, Levine JD, Julius D (1997) The capsaicin receptor: a heat-activated ion channel in the pain pathway. Nature 389:816-824.

Caterina MJ, Leffler A, Malmberg AB, Martin WJ, Trafton J, Petersen-Zeitz KR, Koltzenburg M, Basbaum AI, Julius D (2000) Impaired nociception and pain sensation in mice lacking the capsaicin receptor. Science 288:306-313

Christoph T, Bahrenberg G, De Vry J, Englberger W, Erdmann VA, Frech M, Kögel B, Röhl T, Schiene K, Schröder W, Seibler J, Kurreck J (2008) Investigation of TRPV1 loss-of-function phenotypes in transgenic shRNA expressing and knockout mice. Mol Cell Neurosci 37:579-589.

Crawley JN, Corwin RL, Robinson JK, Felder CC, Devane WA, Axelrod J (1993) Anandamide, an endogenous ligand of the cannabinoid receptor, induces hypomotility and hypothermia in vivo in rodents. Pharmacol Biochem Behav 46:967-972.

Cui M, Honore P, Zhong C, Gauvin D, Mikusa J, Hernandez G, Chandran P, Gomtsyan A, Brown B, Bayburt EK, Marsh K, Bianchi B, McDonald H, Niforatos W, Neelands TR, Moreland RB, Decker MW, Lee CH, Sullivan JP, Faltynek CR (2006) TRPV1 receptors in the CNS play a key role in broad-spectrum analgesia of TRPV1 antagonists. J Neurosci 26:9385-9393.

Davis JB, Gray J, Gunthorpe MJ, Hatcher JP, Davey PT, Overend P, Harries MH, Latcham J, Clapham C, Atkinson K, Hughes SA, Rance K, Grau E, Harper AJ, Pugh PL, Rogers DC, Bingham S, Randall A, Sheardown SA (2000) Vanilloid receptor-1 is essential for inflammatory thermal hyperalgesia. Nature 405:183-187.

de Lago E, de Miguel R, Lastres-Becker I, Ramos JA, Fernández-Ruiz J (2004) Involvement of vanilloid-like receptors in the effects of anandamide on motor behavior and nigrostriatal dopaminergic activity: in vivo and in vitro evidence. Brain Res 1007:152-159.

de Vries DJ, Blumberg PM (1989) Thermoregulatory effects of resiniferatoxin in the mouse: comparison with capsaicin. Life Sci 44:711-715.

Di Marzo V, Breivogel C, Bisogno T, Melck D, Patrick G, Tao Q, Szallasi A, Razdan RK, Martin BR (2000) Neurobehavioral activity in mice of N-vanillyl-arachidonyl-amide. Eur J Pharmacol 406:363-374.

Di Marzo V, Lastres-Becker I, Bisogno T, De Petrocellis L, Milone A, Davis JB, Fernandez-Ruiz JJ (2001) Hypolocomotor effects in rats of capsaicin and two long chain capsaicin homologues. Eur J Pharmacol 420:123-131.

Dogan MD, Patel S, Rudaya AY, Steiner AA, Székely M, Romanovsky AA (2004) Lipopolysaccharide fever is initiated via a capsaicin-sensitive mechanism independent of the subtype-1 vanilloid receptor. Br J Pharmacol 143:1023-1032.

Drizin I, Gomtsyan A, Bayburt EK, Schmidt RG, Zheng GZ, Perner RJ, DiDomenico S, Koenig JR, Turner SC, Jinkerson TK, Brown BS, Keddy RG, McDonald HA, Honore P, Wismer CT, Marsh KC, Wetter JM, Polakowski JS, Segreti JA, Jarvis MF, et al. (2006) Structure-activity studies of a novel series of 5,6-fused heteroaromatic ureas as TRPV1 antagonists. Bioorg Med Chem 14:4740-4749.

Fride E, Mechoulam R (1993) Pharmacological activity of the cannabinoid 
receptor agonist, anandamide, a brain constituent. Eur J Pharmacol 231:313-314.

Garami A, Shimansky YP, Pakai E, Oliveira DL, Gavva NR, Romanovsky AA (2010) Contributions of different modes of TRPV1 activation to TRPV1 antagonist-induced hyperthermia. J Neurosci 30:1435-1440.

Gavva NR (2008) Body-temperature maintenance as the predominant function of the vanilloid receptor TRPV1. Trends Pharmacol Sci 29:550-557.

Gavva NR, Tamir R, Qu Y, Klionsky L, Zhang TJ, Immke D, Wang J, Zhu D, Vanderah TW, Porreca F, Doherty EM, Norman MH, Wild KD, Bannon AW, Louis JC, Treanor JJ (2005) AMG 9810 [(E)-3-(4-t-butylphenyl)$\mathrm{N}$-(2,3-dihydrobenzo[b][1,4] dioxin-6-yl)acrylamide], a novel vanilloid receptor 1 (TRPV1) antagonist with antihyperalgesic properties. J Pharmacol Exp Ther 313:474-484.

Gonsiorek W, Lunn C, Fan X, Narula S, Lundell D, Hipkin RW (2000) Endocannabinoid 2-arachidonyl glycerol is a full agonist through human type 2 cannabinoid receptor: antagonism by anandamide. Mol Pharmacol 57:1045-1050.

Gordon CJ (1994) 24-hour control of body temperature in rats. I. Integration of behavioral and autonomic effectors. Am J Physiol 267:R71-R77.

Hori T (1984) Capsaicin and central control of thermoregulation. Pharmacol Ther 26:389-416.

Huffman DM, Barzilai N (2009) Role of visceral adipose tissue in aging. Biochim Biophys Acta 1790:1117-1123.

Hunt JL, Zaretsky DV, Sarkar S, Dimicco JA (2010) Dorsomedial hypothalamus mediates autonomic, neuroendocrine, and locomotor responses evoked from the medial preoptic area. Am J Physiol Regul Integr Comp Physiol 298:R130-R140.

Iida T, Shimizu I, Nealen ML, Campbell A, Caterina M (2005) Attenuated fever response in mice lacking TRPV1. Neurosci Lett 378:28-33.

Inoue R, Jensen LJ, Shi J, Morita H, Nishida M, Honda A, Ito Y (2006) Transient receptor potential channels in cardiovascular function and disease. Circ Res 99:119-131.

Kanizsai P, Garami A, Solymár M, Szolcsányi J, Szelényi Z (2009) Energetics of fasting heterothermia in TRPV1-KO and wild type mice. Physiol Behav 96:149-154.

Kawabata F, Inoue N, Yazawa S, Kawada T, Inoue K, Fushiki T (2006) Effects of $\mathrm{CH}-19$ sweet, a non-pungent cultivar of red pepper, in decreasing the body weight and suppressing body fat accumulation by sympathetic nerve activation in humans. Biosci Biotechnol Biochem 70:2824-2835.

Lee J, Di Marzo V, Brotchie JM (2006) A role for vanilloid receptor 1 (TRPV1) and endocannabinnoid signalling in the regulation of spontaneous and L-DOPA induced locomotion in normal and reserpine-treated rats. Neuropharmacology 51:557-565.

Lesnikov VA, Tsvetkova IP (1985) Stereotaxic coordinates of the mouse hypothalamus (in Russian). Fiziol Zh SSSR Im I M Sechenova 71:798-804.

Lundbaek JA, Birn P, Tape SE, Toombes GE, Søgaard R, Koeppe RE 2nd, Gruner SM, Hansen AJ, Andersen OS (2005) Capsaicin regulates voltage-dependent sodium channels by altering lipid bilayer elasticity. Mol Pharmacol 68:680-689.

Mandadi S, Nakanishi ST, Takashima Y, Dhaka A, Patapoutian A, McKemy DD, Whelan PJ (2009) Locomotor networks are targets of modulation by sensory transient receptor potential vanilloid 1 and transient receptor potential melastatin 8 channels. Neuroscience 162:1377-1397.

Marsch R, Foeller E, Rammes G, Bunck M, Kössl M, Holsboer F, Zieglgänsberger W, Landgraf R, Lutz B, Wotjak CT (2007) Reduced anxiety, conditioned fear, and hippocampal long-term potentiation in transient receptor potential vanilloid type 1 receptor-deficient mice. J Neurosci 27:832-839.

McAllen RM, Tanaka M, Ootsuka Y, McKinley MJ (2010) Multiple thermoregulatory effectors with independent central controls. Eur J Appl Physiol 109:27-33.

Mills C, McMackin M, Jaffe R, Yu J, Zininberg E, Slee D, Gogas K, Bradbury M (2008) Effects of the transient receptor potential vanilloid 1 antagonist A-425619 on body temperature and thermoregulation in the rat. Neuroscience 156:165-174.

Morrison SF, Nakamura K, Madden CJ (2008) Central control of thermogenesis. Exp Physiol 93:773-797.

Motter AL, Ahern GP (2008) TRPV1-null mice are protected from dietinduced obesity. FEBS Lett 582:2257-2262.

Mount LE, Willmott JV (1967) The relation between spontaneous activity, metabolic rate and the 24 hour cycle in mice at different environmental temperatures. J Physiol 190:371-380.

Nikami H, Mahmoud ME, Shimizu Y, Shiina T, Hirayama H, Iwami M, Dosoky RM, Ahmed MM, Takewaki T (2008) Capsaicin pretreatment attenuates LPS-induced hypothermia through TRPV1-independent mechanisms in chicken. Life Sci 82:1191-1195.

Nilius B, Owsianik G, Voets T, Peters JA (2007) Transient receptor potential cation channels in disease. Physiol Rev 87:165-217.

Panlilio LV, Mazzola C, Medalie J, Hahn B, Justinova Z, Drago F, Cadet JL, Yasar S, Goldberg SR (2009) Anandamide-induced behavioral disruption through a vanilloid-dependent mechanism in rats. Psychopharmacology (Berl) 203:529-538.

Proulx K, Cota D, Castañeda TR, Tschöp MH, D’Alessio DA, Tso P, Woods SC, Seeley RJ (2005) Mechanisms of oleoylethanolamide-induced changes in feeding behavior and motor activity. Am J Physiol Regul Integr Comp Physiol 289:R729-R737.

Romanovsky AA (2007) Thermoregulation: some concepts have changed. Functional architecture of the thermoregulatory system. Am J Physiol Regul Integr Comp Physiol 292:R37-R46.

Romanovsky AA, Ivanov AI, Shimansky YP (2002) Selected contribution: ambient temperature for experiments in rats: a new method for determining the zone of thermal neutrality. J Appl Physiol 92:2667-2679.

Romanovsky AA, Almeida MC, Garami A, Steiner AA, Norman MH, Morrison SF, Nakamura K, Burmeister JJ, Nucci TB (2009) The transient receptor potential vanilloid- 1 channel in thermoregulation: a thermosensor it is not. Pharmacol Rev 61:228-261.

Rong W, Hillsley K, Davis JB, Hicks G, Winchester WJ, Grundy D (2004) Jejunal afferent nerve sensitivity in wild-type and TRPV1 knockout mice. J Physiol 560:867-881.

Rudaya AY, Steiner AA, Robbins JR, Dragic AS, Romanovsky AA (2005) Thermoregulatory responses to lipopolysaccharide in the mouse: dependence on the dose and ambient temperature. Am J Physiol Regul Integr Comp Physiol 289:R1244-R1252.

Sharif-Naeini R, Ciura S, Zhang Z, Bourque CW (2008) Contribution of TRPV channels to osmosensory transduction, thirst, and vasopressin release. Kidney Int 73:811-815.

Smart D, Gunthorpe MJ, Jerman JC, Nasir S, Gray J, Muir AI, Chambers JK, Randall AD, Davis JB (2000) The endogenous lipid anandamide is a full agonist at the human vanilloid receptor (hVR1). Br J Pharmacol 129:227-230.

Smith PB, Compton DR, Welch SP, Razdan RK, Mechoulam R, Martin BR (1994) The pharmacological activity of anandamide, a putative endogenous cannabinoid, in mice. J Pharmacol Exp Ther 270:219-227.

Snitker S, Fujishima Y, Shen H, Ott S, Pi-Sunyer X, Furuhata Y, Sato H, Takahashi M (2009) Effects of novel capsinoid treatment on fatness and energy metabolism in humans: possible pharmacogenetic implications. Am J Clin Nutr 89:45-50.

Steiner AA, Turek VF, Almeida MC, Burmeister JJ, Oliveira DL, Roberts JL, Bannon AW, Norman MH, Louis JC, Treanor JJ, Gavva NR, Romanovsky AA (2007) Nonthermal activation of transient receptor potential vanilloid-1 channels in abdominal viscera tonically inhibits autonomic cold-defense effectors. J Neurosci 27:7459-7468.

Suri A, Szallasi A (2008) The emerging role of TRPV1 in diabetes and obesity. Trends Pharmacol Sci 29:29-36.

Szallasi A, Nilsson S, Farkas-Szallasi T, Blumberg PM, Hökfelt T, Lundberg JM (1995) Vanilloid (capsaicin) receptors in the rat: distribution in the brain, regional differences in the spinal cord, axonal transport to the periphery, and depletion by systemic vanilloid treatment. Brain Res 703:175-183.

Szallasi A, Cortright DN, Blum CA, Eid SR (2007) The vanilloid receptor TRPV1: 10 years from channel cloning to antagonist proof-of-concept. Nat Rev Drug Discov 6:357-372.

Szelényi Z, Hummel Z, Szolcsányi J, Davis JB (2004) Daily body temperature rhythm and heat tolerance in TRPV1 knockout and capsaicin pretreated mice. Eur J Neurosci 19:1421-1424.

Szentirmai E, Kapás L, Sun Y, Smith RG, Krueger JM (2010) Restricted feeding-induced sleep, activity, and body temperature changes in normal and preproghrelin-deficient mice. Am J Physiol Regul Integr Comp Physiol 298:R467-R477.

Takeda Y, Ishida T, Tsutsui R, Toide K, Tanimoto-Mori S, Watanabe S, Kanai Y, Kamei C (2008) Studies on somnolence in the daytime caused by drugs used for neuropathic pain. J Pharmacol Sci 107:246-250. 
Tominaga M, Caterina MJ, Malmberg AB, Rosen TA, Gilbert H, Skinner K, Raumann BE, Basbaum AI, Julius D (1998) The cloned capsaicin receptor integrates multiple pain-producing stimuli. Neuron 21:531-543.

Tzavara ET, Li DL, Moutsimilli L, Bisogno T, Di Marzo V, Phebus LA, Nomikos GG, Giros B (2006) Endocannabinoids activate transient receptor potential vanilloid 1 receptors to reduce hyperdopaminergiarelated hyperactivity: therapeutic implications. Biol Psychiatry 59:508515.

Vogel Z, Barg J, Levy R, Saya D, Heldman E, Mechoulam R (1993) Anandamide, a brain endogenous compound, interacts specifically with cannabinoid receptors and inhibits adenylate cyclase. J Neurochem 61:352-355.

Watanabe K, Matsunaga T, Nakamura S, Kimura T, Ho IK, Yoshimura H, Yamamoto I (1999) Pharmacological effects in mice of anandamide and its related fatty acid ethanolamides, and enhancement of cataleptogenic effect of anandamide by phenylmethylsulfonyl fluoride. Biol Pharm Bull 22:366-370.

Weinert D, Waterhouse J (1998) Diurnally changing effects of locomotor activity on body temperature in laboratory mice. Physiol Behav 63:837-843.

Westerterp KR, Plasqui G (2009) Physically active lifestyle does not decrease the risk of fattening. PLoS One 4:e4745.

Wiley JL, Razdan RK, Martin BR (2006) Evaluation of the role of the arachidonic acid cascade in anandamide's in vivo effects in mice. Life Sci 80:24-35.

Wise LE, Shelton CC, Cravatt BF, Martin BR, Lichtman AH (2007) Assessment of anandamide's pharmacological effects in mice deficient of both fatty acid amide hydrolase and cannabinoid CB1 receptors. Eur J Pharmacol 557:44-48.

Zhang LL, Yan Liu D, Ma LQ, Luo ZD, Cao TB, Zhong J, Yan ZC, Wang LJ, Zhao ZG, Zhu SJ, Schrader M, Thilo F, Zhu ZM, Tepel M (2007) Activation of transient receptor potential vanilloid type-1 channel prevents adipogenesis and obesity. Circ Res 100:1063-1070.

Zygmunt PM, Petersson J, Andersson DA, Chuang H, Sørgård M, Di Marzo V, Julius D, Högestätt ED (1999) Vanilloid receptors on sensory nerves mediate the vasodilator action of anandamide. Nature 400:452-457. 